\title{
Carbon cycling in the North American coastal ocean: a synthesis
}

\author{
Katja Fennel $^{1}$, Simone Alin ${ }^{2}$, Leticia Barbero ${ }^{3}$, Wiley Evans ${ }^{4}$, Timothée Bourgeois ${ }^{1}$, Sarah Cooley ${ }^{5}$, John Dunne ${ }^{6}$, \\ Richard A. Feely ${ }^{2}$, Jose Martin Hernandez-Ayon ${ }^{7}$, Xinping $\mathbf{H u}^{8}$, Steven Lohrenz ${ }^{9}$, Frank Muller-Karger ${ }^{10}$, \\ Raymond Najjar $^{11}$, Lisa Robbins ${ }^{10}$, Elizabeth Shadwick ${ }^{12}$, Samantha Siedlecki ${ }^{13}$, Nadja Steiner ${ }^{14}$, Adrienne Sutton ${ }^{2}$, \\ Daniela Turk $^{15}$, Penny Vlahos ${ }^{13}$, and Zhaohui Aleck Wang ${ }^{16}$ \\ ${ }^{1}$ Department of Oceanography, Dalhousie University, 1355 Oxford Street, Halifax B3H 4R2, Nova Scotia, Canada \\ ${ }^{2}$ NOAA Pacific Marine Environmental Laboratory, Seattle, WA 98115, USA \\ ${ }^{3}$ NOAA Atlantic Oceanographic and Meteorological Laboratory, Miami, FL 33149, USA \\ ${ }^{4}$ Hakai Institute, Campbell River, BC, V9W 0B7, Canada \\ ${ }^{5}$ Ocean Conservancy, USA \\ ${ }^{6}$ NOAA Geophysical Fluid Dynamics Laboratory, Princeton, NJ 08540, USA \\ ${ }^{7}$ Department of Marine Science, Autonomous University of Baja California, Ensenada, Baja California, CP 228600, Mexico \\ ${ }^{8}$ Department of Physical and Environmental Sciences, Texas A\&M University, Corpus Christi, TX 78412, USA \\ ${ }^{9}$ School for Marine Science and Technology, University of Massachusetts, Dartmouth, MA 02747, USA \\ ${ }^{10}$ Department of Marine Science, University of South Florida, Tampa, FL 33620, USA \\ ${ }^{11}$ Department of Meteorology and Atmospheric Sciences, University Park, Pennsylvania 16802, USA \\ ${ }^{12}$ The Department is Oceans \& Atmosphere. The Institution is CSIRO, Hobart, TAS 7000, Australia \\ ${ }^{13}$ Marine Sciences, University of Connecticut, Groton, CT 06340, USA \\ ${ }^{14}$ Department of Fisheries and Oceans Canada, Sidney, BC V8L 4B2, Canada \\ ${ }^{15}$ Lamont-Doherty Earth Observatory, Palisades, NY 10964, USA \\ ${ }^{16}$ Woods Hole Oceanographic Institution, Woods Hole, MA 02543, USA
}

Correspondence: Katja Fennel (katja.fennel@dal.ca)

Received: 19 September 2018 - Discussion started: 20 September 2018

Revised: 28 February 2019 - Accepted: 8 March 2019 - Published: 27 March 2019

\begin{abstract}
A quantification of carbon fluxes in the coastal ocean and across its boundaries with the atmosphere, land, and the open ocean is important for assessing the current state and projecting future trends in ocean carbon uptake and coastal ocean acidification, but this is currently a missing component of global carbon budgeting. This synthesis reviews recent progress in characterizing these carbon fluxes for the North American coastal ocean. Several observing networks and high-resolution regional models are now available. Recent efforts have focused primarily on quantifying the net air-sea exchange of carbon dioxide $\left(\mathrm{CO}_{2}\right)$. Some studies have estimated other key fluxes, such as the exchange of organic and inorganic carbon between shelves and the open ocean. Available estimates of air-sea $\mathrm{CO}_{2}$ flux, informed by more than a decade of observations, indicate that the North American Exclusive Economic Zone (EEZ) acts as a sink of $160 \pm 80 \mathrm{Tg} \mathrm{Cyr}^{-1}$, although this flux is not
\end{abstract}

well constrained. The Arctic and sub-Arctic, mid-latitude Atlantic, and mid-latitude Pacific portions of the EEZ account for 104,62 , and $-3.7 \mathrm{Tg} \mathrm{C} \mathrm{yr}^{-1}$, respectively, while making up $51 \%, 25 \%$, and $24 \%$ of the total area, respectively. Combining the net uptake of $160 \pm 80 \mathrm{Tg} \mathrm{C} \mathrm{yr}^{-1}$ with an estimated carbon input from land of $106 \pm 30 \mathrm{Tg} \mathrm{C} \mathrm{yr}^{-1}$ minus an estimated burial of $65 \pm 55 \mathrm{Tg} \mathrm{Cyr}^{-1}$ and an estimated accumulation of dissolved carbon in EEZ waters of $50 \pm 25 \mathrm{Tg} \mathrm{C} \mathrm{yr}^{-1}$ implies a carbon export of $151 \pm 105 \mathrm{Tg} \mathrm{C} \mathrm{yr}^{-1}$ to the open ocean. The increasing concentration of inorganic carbon in coastal and open-ocean waters leads to ocean acidification. As a result, conditions favoring the dissolution of calcium carbonate occur regularly in subsurface coastal waters in the Arctic, which are naturally prone to low $\mathrm{pH}$, and the North Pacific, where upwelling of deep, carbon-rich waters has intensified. Expanded monitoring and extension of existing model capabilities are required to provide more reli- 
able coastal carbon budgets, projections of future states of the coastal ocean, and quantification of anthropogenic carbon contributions.

\section{Introduction}

Along ocean margins, the atmospheric, terrestrial, sedimentary, and deep-ocean carbon reservoirs meet, resulting in quantitatively significant carbon exchanges. Although continental shelves make up only $7 \%$ to $10 \%$ of the global ocean surface area, they are estimated to contribute up to $30 \%$ of primary production, $30 \%$ to $50 \%$ of inorganic carbon burial, and $80 \%$ of organic carbon burial (Dunne et al., 2007; Gattuso et al., 1998). As such, continental shelves have been argued to contribute disproportionately to the oceanic uptake of $\mathrm{CO}_{2}$ (Cai, 2011; Liu et al., 2010; Muller-Karger et al., 2005). Anthropogenic activities have led to secular trends in carbon exchanges along ocean margins. The drivers underlying the secular trends include rising atmospheric carbon dioxide $\left(\mathrm{CO}_{2}\right)$ levels, climate-driven changes in atmospheric forcing (e.g., winds and heat fluxes), ocean circulation, and the hydrological cycle (e.g., freshwater input from rivers), and changes in riverine and atmospheric nutrient inputs from agricultural activities, urbanization, fossil fuel burning, and other human activities. The collective impact of these factors on carbon processing and exchanges along ocean margins is complex and difficult to quantify (Regnier et al., 2013).

This review aims to summarize recent findings with respect to coastal carbon uptake and ocean acidification for the ocean margins of North America (Fig. 1) and was conducted as part of the second State of the Carbon Cycle Report (SOCCR-2). The review builds on and extends several previous activities, including a report by the North American Continental Margins Working Group (Hales et al., 2008), the first State of the Carbon Cycle Report (SOCCR-1; King et al., 2007), and activities within the North American coastal interim synthesis (Benway et al., 2016; Benway and Coble, 2014; Najjar et al., 2012).

A decade ago in SOCCR-1, Chavez et al. (2007) concluded that carbon fluxes for North American coastal margins were not well quantified because of insufficient observations and the complexity and highly localized spatial variability of coastal carbon dynamics. The report was inconclusive as to whether North American coastal waters act as an overall source or sink of atmospheric $\mathrm{CO}_{2}$. Here we revisit the question of whether the coastal ocean of North America takes up atmospheric $\mathrm{CO}_{2}$ and subsequently exports it to the deep ocean, and we discuss patterns and drivers of coastal ocean acidification. The first topic is relevant to overall quantification of the ocean's uptake of $\mathrm{CO}_{2}$. The second is directly relevant to coastal ecosystem health, fisheries, and aquaculture. The review does not consider estuarine waters and tidal wetlands as these are the subject of a separate activity (Windham-Myers et al., 2018).

Two different terms will be used here when referring to ocean margins: coastal oceans, defined here as non-estuarine waters within 200 nautical miles $(370 \mathrm{~km})$ of the coast, and continental shelves, which refer to the submerged margins of the continental plates, operationally defined as regions with water depths shallower than $200 \mathrm{~m}$ (indicated in gray in Fig. 1). Although the two definitions overlap, there are important reasons for considering both. Along passive margins with broad shelves like the Atlantic coast, the continental shelf is the relevant spatial unit for discussing carbon fluxes. Along active margins with narrow shelves, such as the Pacific coast, a larger region than just the shelf needs to be considered to meaningfully discuss coastal carbon dynamics. The $370 \mathrm{~km}$ limit was recommended by Hales et al. (2008) and corresponds to the Exclusive Economic Zone (EEZ), i.e., the region where a nation can claim exclusive rights for fishing, drilling, and other economic activities. Worth noting here is that ocean $\mathrm{CO}_{2}$ uptake or loss is not credited to any nation under Intergovernmental Panel on Climate Change (IPCC) $\mathrm{CO}_{2}$ accounting; instead, ocean uptake is viewed as an internationally shared public commons.

This review is structured as follows. First, we summarize the key variables and fluxes relevant to carbon budgets for coastal waters, summarize the mechanisms by which carbon can be removed from the atmosphere, and describe the means for quantifying the resulting carbon removal (see Sect. 2). Next, we present available research relevant to carbon budgets for North American coastal waters by region and derive a carbon budget for the North American EEZ (see Sect. 3). Last, we discuss climate-driven trends in coastal carbon fluxes and coastal ocean acidification (see Sect. 4), followed by conclusions.

\section{General overview of coastal carbon fluxes and stocks}

Carbon is constantly transferred among different pools and exchanged across the interfaces that demarcate coastal waters: the land-ocean interface, the air-sea interface, and the interface between coastal and open-ocean waters. Of major importance are the conversion of dissolved inorganic carbon (DIC) into particulate and dissolved organic carbon (POC and DOC), through primary production, and the reverse transformation by respiration throughout the water column, returning most of the organic carbon back into DIC. Some POC settles out of the water column and becomes incorporated into the sediments where most of this material is respired through a range of different redox processes that produce DIC and, in the absence of electron acceptors other than $\mathrm{CO}_{2}, \mathrm{CH}_{4}$. Both DIC and $\mathrm{CH}_{4}$ are released back into the overlying water. POC that is not respired can be buried in sediments and stored for a very long time. Some organisms also precipitate internal or external body structures of 


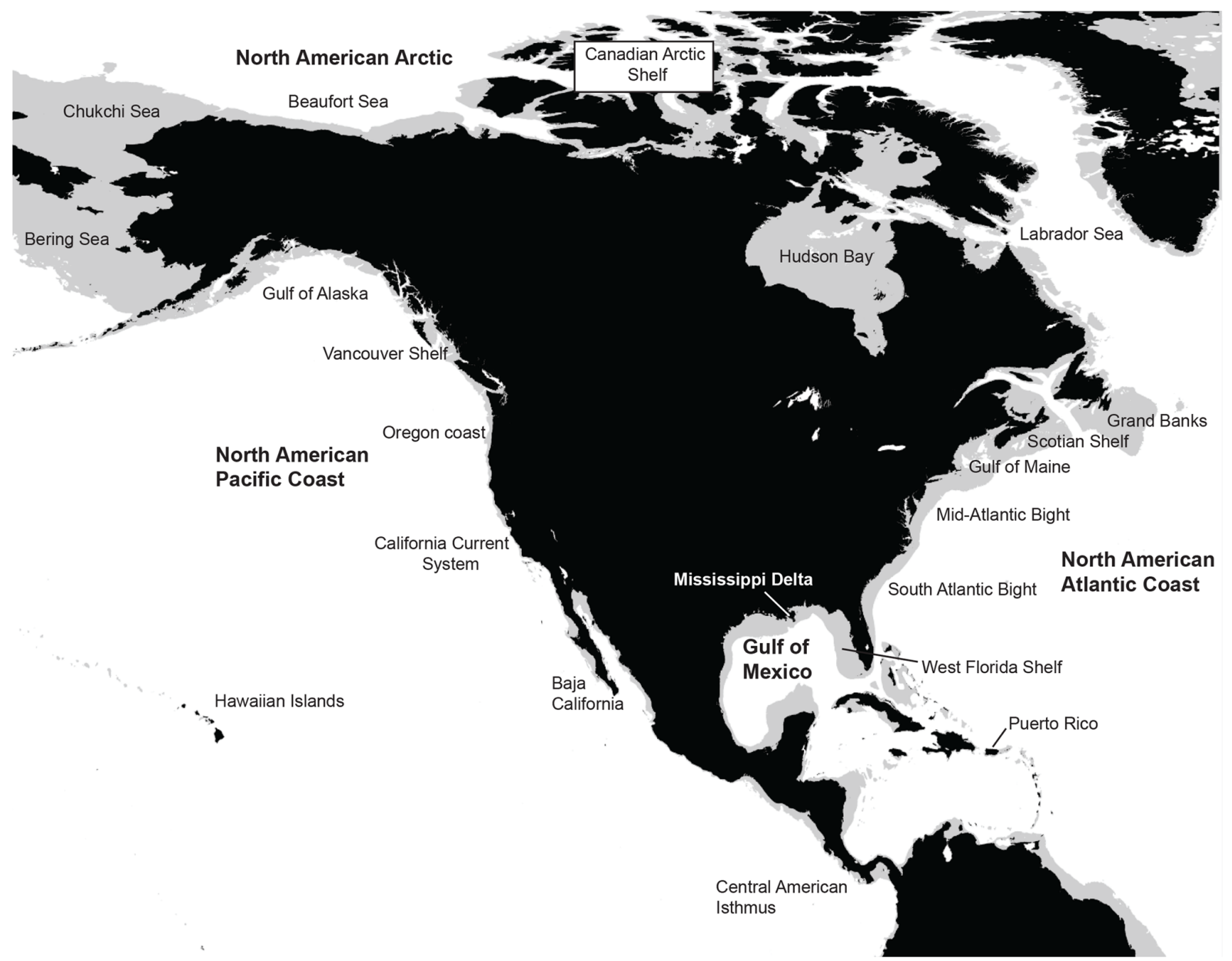

Figure 1. North American continent (in black) with shelf seas (in gray) defined as waters with bottom depths less than $200 \mathrm{~m}$. The easternmost tip of Asia and northern part of South America are also shown in black.

$\mathrm{CaCO}_{3}$, which either dissolve or become incorporated into the sediments and are buried. This discussion will refer to the long-term storage of carbon in coastal sediments as permanent burial.

A major carbon exchange process along ocean margins is the flux of $\mathrm{CO}_{2}$ across the air-sea interface. The annual cycle of this flux is driven by the undersaturation or oversaturation of surface ocean $\mathrm{CO}_{2}$ resulting from ocean temperature changes (which affect $\mathrm{CO}_{2}$ solubility), from primary production, respiration, and $\mathrm{CaCO}_{3}$ precipitation and dissolution, and the transport of DIC to and from the ocean surface (e.g., by upwelling and convection). Other factors that influence gas exchange across the air-sea interface are winds, sea ice extent, and surface films. Other important exchange fluxes are organic and inorganic carbon inputs from land via rivers and estuaries (Najjar et al., 2018), inputs from tidal wetlands (Ho et al., 2017), and exchanges between the coastal and open oceans across the continental shelf break or the operationally defined open-ocean boundary of the coastal ocean (Fennel, 2010). Net removal of carbon from direct interaction with the atmosphere can occur through the export of carbon to the deep ocean or permanent burial in coastal sediments.

Carbon export, referring to the flux of organic and inorganic carbon from coastal waters to the deep ocean, can occur through the so-called continental shelf pump - a term coined by Tsunogai et al. (1999) after they observed a large uptake of atmospheric $\mathrm{CO}_{2}$ in the East China Sea. There are two distinct mechanisms underlying the continental shelf pump (Fennel, 2010). The first is physical in nature and thought to operate in mid- and high-latitude systems. In winter, shelf water is cooled more strongly than surface water in the adjacent open ocean because the former is not subject to deep convection (Ivanov et al., 2004; Canals et al., 2006). The colder shelf water is denser and experiences a larger influx of atmospheric $\mathrm{CO}_{2}$; both density and the solubility of $\mathrm{CO}_{2}$ increase with decreasing temperature. If this dense and carbonrich water is transported off the shelf, it will sink due to its higher density, and the associated carbon will be exported to the deep ocean. The second mechanism relies on biological processes that concentrate carbon below the seasonal pycn- 
ocline through the photosynthetic production of organic carbon and subsequent sinking. If the carbon-rich water below the seasonal pycnocline is moved off the shelf horizontally, carbon could potentially be exported if this water is transported or mixed below the seasonal thermocline. The depth to which the shelf-derived carbon can be exported is different for POC, which would sink, and DOC and DIC, which would primarily be advected laterally. Both mechanisms for carbon export critically depend on the physical transport of carbon-rich water off the shelf.

Carbon export flux from coastal waters to the deep ocean cannot be quantified easily or accurately through direct observation, especially considering the three-dimensional nature of exchanges between the coastal and open ocean (Frischknecht et al., 2018). Thus, the only available estimates of such export are indirect, using mass balances of POC and dissolved oxygen (Hales et al., 2006), mass balances of DOC (Barrón and Duarte, 2015; Vlahos et al., 2002), mass balances of TOC and DIC (Najjar et al., 2018), or model estimates (Izett and Fennel, 2018a, b; Bourgeois et al., 2016; Fennel and Wilkin, 2009; Mannino et al., 2016; Xue et al., 2013; Frischknecht et al., 2018). If the total carbon inventory in a coastal system can be considered constant over a sufficiently long timescale (i.e., of the order of years), inferring carbon export is possible using the sum of all other exchange fluxes across the system's interfaces over that same period. Export to the open ocean must balance the influx of carbon from land and wetlands, its net exchange across the air-sea interface, lateral exchange caused by advection, and any removal through permanent sediment burial. The accuracy of the inferred export flux directly depends on the accuracy of the other flux estimates and of the assumption of a constant carbon inventory. Quantifying internal transformation processes (e.g., respiration, primary and secondary production) does not directly enter this budgeting approach but can elucidate the processes that drive fluxes across interfaces.

Current estimates of carbon fluxes across coastal interfaces come with significant uncertainties (Regnier et al., 2013). These uncertainties are caused by a combination of small-scale temporal and spatial variability, which is undersampled by currently available means of direct observation, and regional heterogeneity, which makes scaling up observations from one region to larger areas difficult. Contributing to variability in regional carbon budgets and export are geographical differences arising from variations in shelf width, upwelling strength, the presence or absence of large rivers, seasonal ice cover, and latitude. Section 3 describes the regional characteristics of North American coastal waters and how these characteristics influence carbon dynamics.

The motivation for quantifying the permanent burial of organic carbon and the export of carbon from coastal waters to the deep ocean is that both processes remove $\mathrm{CO}_{2}$ from the atmospheric reservoir. A more relevant but harder to obtain quantity in this context is the burial or export of anthropogenic carbon, i.e., the carbon that was added to the atmosphere by anthropogenic activities. Present-day carbon fluxes represent a superposition of the anthropogenic flux component and the natural background flux (see McNeil and Matear, 2013, for further details). Only total fluxes - the sum of anthropogenic and background fluxes - can be observed directly. Distinction between anthropogenic fluxes and the natural background is difficult to assess for coastal ocean fluxes and has to rely on process-based arguments and models (Regnier et al., 2013).

\section{Review of coastal carbon fluxes around North America}

In this section we briefly describe the bathymetric and hydrographical features of the four major North American coastal margins (the Atlantic coast, the Pacific coast, the coast of the northern Gulf of Mexico, and the Arctic coast), followed by a review of available carbon flux estimates for each. Where multiple flux estimates are available for the same region it is important to keep in mind that their spatial footprints and time windows do not necessarily match exactly.

\subsection{Atlantic coast}

The North American Atlantic coast borders a wide, geologically passive-margin shelf that extends from the southern tip of Florida to the continental shelf of the Labrador Sea (Fig. 1). The shelf is several hundred kilometers wide in the north (Labrador shelf and Grand Banks) but narrows progressively toward the south in the Mid-Atlantic Bight (MAB), which is between Cape Cod and Cape Hatteras, and the South Atlantic Bight (SAB), which is south of Cape Hatteras. The $\mathrm{SAB}$ shelf width measures only several tens of kilometers. Two major semi-enclosed bodies of water are the Gulf of Maine (GOM) and Gulf of St. Lawrence. Important rivers and estuaries north of Cape Hatteras include the St. Lawrence River and Estuary, the Hudson River, Long Island Sound, Delaware Bay, and Chesapeake Bay. South of Cape Hatteras, the coastline is characterized by small rivers and marshes.

The SAB is impacted by the Gulf Stream, which flows northeastward along the shelf edge before detaching at Cape Hatteras and meandering eastward into the open North Atlantic Ocean. North of Cape Hatteras, shelf circulation is influenced by the confluence of the southwestward-flowing fresh and cold shelf-break current (a limb of the Labrador Current) and the warm and salty Gulf Stream (Loder, 1998). Because shelf waters north of Cape Hatteras are sourced from the Labrador Sea, they are relatively cold, fresh, and carbon rich, while slope waters (those located between the shelf break and the northern wall of the Gulf Stream) are a mixture of Labrador Current and Gulf Stream water. South of Cape Hatteras, exchange between the shelf and open ocean across the shelf break is impeded by the presence of the Gulf Stream and occurs via baroclinic instabilities in its north- 


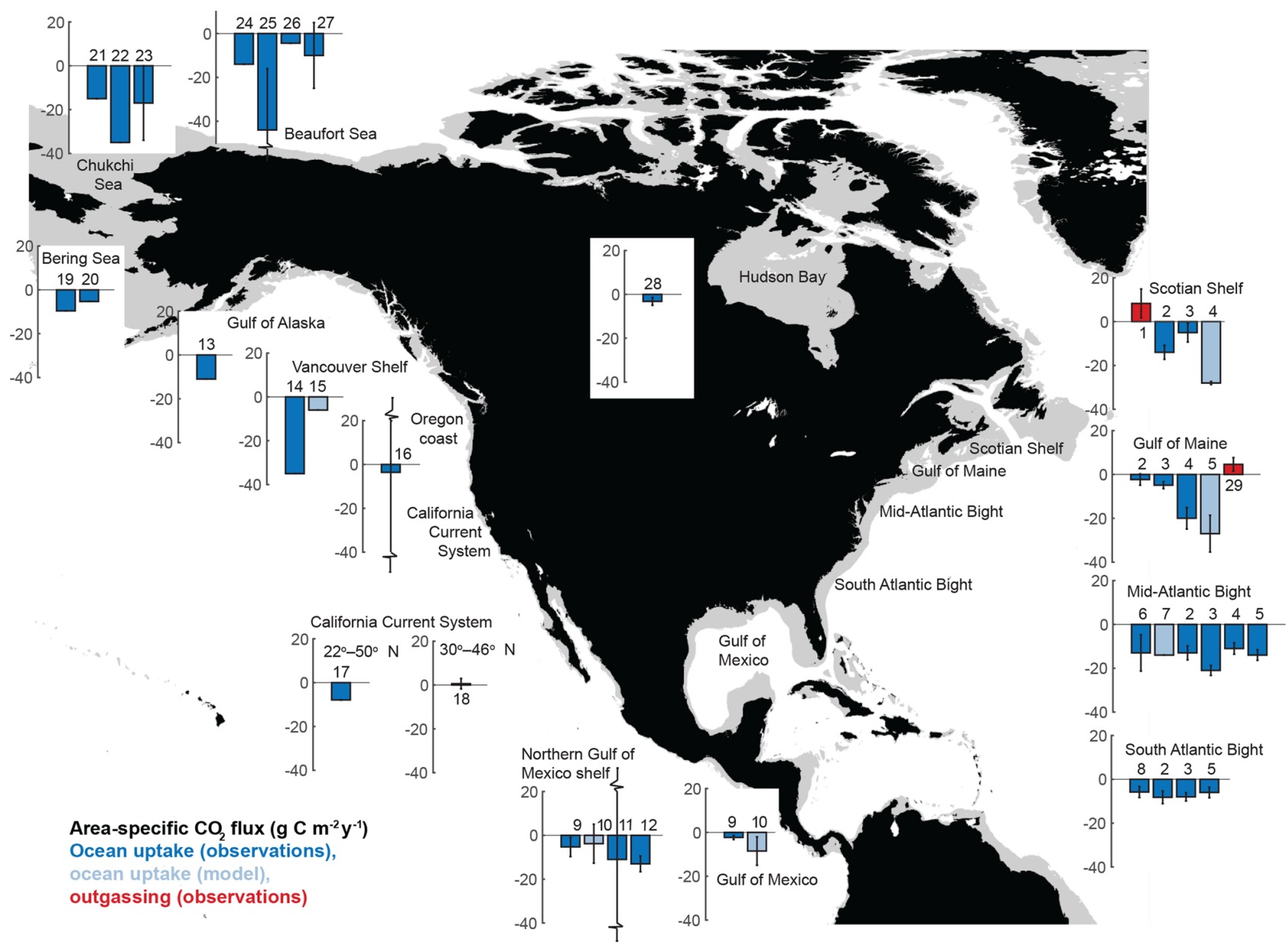

Figure 2. Observation- and model-based estimates of regional net air-sea $\mathrm{CO}_{2}$ flux in $\mathrm{g} \mathrm{C} \mathrm{m}^{-2} \mathrm{yr}^{-1}$. Positive fluxes (red bars) indicate a flux to the atmosphere. Observation-based estimates are shown in red and dark blue. Model-based estimates are in light blue. Broken error bars are used where errors bars reach outside the range of the $y$ axis. References: (1) Shadwick et al. (2010), (2) Signorini et al. (2013) using Ho et al. (2011) gas transfer parameterization, (3) satellite-based estimate from 2, (4) Fennel and Wilkin (2009), (5) Cahill et al. (2016), (6) DeGrandpre et al. (2002), (7) Fennel et al. (2008), (8) Jiang et al. (2008), (9) Robbins et al. (2014), (10) Z. Xue et al. (2016), (11) Huang et al. (2015), (12) Lohrenz et al. (2018), (13) Evans and Mathis (2013), (14) Evans et al. (2012), (15) Ianson and Allen (2002), (16) Evans et al. (2011), (17) Hales et al. (2012), (18) Turi et al. (2014), (19) Cross et al. (2014b), (20) Takahashi et al. (2009), (21) Evans et al. (2015b), (22) Gao et al. (2012), (23) Yasunaka et al. (2016), (24) Shadwick et al. (2011), (25) Else et al. (2013), (26) Evans et al. (2015b), (27) Mucci et al. (2010), (28) Else et al. (2008), (29) Vandemark et al. (2011). The flux estimates are also reported in Table S1 in the Supplement.

ern wall (Lee et al., 1991). In the MAB and on the Scotian Shelf, cross-shelf exchange is hindered by shelf-break jets and fronts (Rutherford and Fennel, 2018).

Air-sea fluxes of $\mathrm{CO}_{2}$ exhibit a large-scale latitudinal gradient along the Atlantic coast (Fig. 2) and significant seasonal and interannual variability (Fig. 3). Discrepancies in independent estimates of net air-sea flux are largest for the Scotian Shelf and the Gulf of Maine (Fig. 2). For the Scotian Shelf, Shadwick et al. (2010), combining in situ and satellite observations, reported a large source of $\mathrm{CO}_{2}$ to the atmosphere of $8.3 \pm 6.6 \mathrm{~g} \mathrm{C} \mathrm{m}^{-2} \mathrm{yr}^{-1}$. In contrast, Signorini et al. (2013) estimated a relatively large sink of atmospheric $\mathrm{CO}_{2}, 14 \pm 3.2 \mathrm{~g} \mathrm{C} \mathrm{m}^{-2} \mathrm{yr}^{-1}$, when using in situ data alone and a much smaller uptake, $5.0 \pm 4.3 \mathrm{~g} \mathrm{C} \mathrm{m}^{-2} \mathrm{yr}^{-1}$, from a combination of in situ and satellite observations. The open GOM (excluding the tidally mixed Georges Bank and Nantucket Shoals) was reported as a weak net source of $4.6 \pm 3.1 \mathrm{~g} \mathrm{C} \mathrm{m}^{-2} \mathrm{yr}^{-1}$ by Vandemark et al. (2011) but with significant interannual variability, while Signorini et al. (2013) estimated the region to be neutral (Table S1). The shallow, tidally mixed Georges Bank and Nantucket Shoals are thought to be sinks, however (Table S1).

The MAB and SAB are consistently estimated to be net sinks. Observation-based estimates for the MAB sink are $13 \pm 8.3$ (DeGrandpre et al., 2002) and $13 \pm 3.2 \mathrm{~g} \mathrm{C} \mathrm{m}^{-2} \mathrm{yr}^{-1}$ (Signorini et al., 2013). Estimates for the SAB sink are $5.8 \pm 2.5$ (Jiang et al., 2008) and $8.2 \pm 2.9 \mathrm{~g} \mathrm{C} \mathrm{m}^{-2} \mathrm{yr}^{-1}$ (Signorini et al., 2013). The transition from a neutral or occa- 
sional net source on the Scotian Shelf and in the GOM to a net sink in the MAB arises because the properties of shelf water are modified during its southwestward flow by air-sea exchange, inflows of riverine and estuarine waters (Salisbury et al., 2008, 2009), and exchange with the open North Atlantic across the shelf break (Cai et al., 2010b; Wang et al., 2013). The cold, carbon-rich water on the Scotian Shelf carries a pronounced signature of its Labrador Sea origin. The GOM, which is deeper than the Scotian Shelf and the MAB and connected to the open North Atlantic through a relatively deep channel, is characterized by a mixture of cold, carbonrich shelf waters entering from the Scotian Shelf and warmer, saltier slope waters. Shelf water in the MAB is sourced from the GOM and is thus a mixture of Scotian Shelf and slope water.

Shelf water in the $\mathrm{SAB}$ is distinct from that in the MAB and has almost no trace of Labrador Current water; instead, its characteristics are similar to those of the Gulf Stream, but its carbon signature is modified by significant organic and inorganic carbon and alkalinity inputs from coastal marshes (Cai et al., 2003; Jiang et al., 2013; Wang and Cai, 2004; Wang et al., 2005). Herrmann et al. (2015) estimated that $59 \%$ of the $3.4 \mathrm{Tg} \mathrm{Cyr}^{-1}$ of organic carbon export from US East Coast estuaries occurs in the SAB. The subsequent respiration of this organic matter and direct outgassing of marsh-derived carbon make the nearshore regions a significant $\mathrm{CO}_{2}$ source almost year-round. Despite the carbon inputs from marshes, the uptake of $\mathrm{CO}_{2}$ on the mid-shelf and outer-shelf regions during the winter months is large enough to balance $\mathrm{CO}_{2}$ outgassing in the other seasons and on the inner shelf, making the SAB an overall weak sink (Jiang et al., 2008).

The seasonality of $\mathrm{CO}_{2}$ dynamics along the Atlantic coast varies with latitude. North of Cape Hatteras, $\mathrm{CO}_{2}$ dynamics are characterized by strong seasonality with solubility-driven uptake by cooling in winter and biologically driven uptake in spring followed by outgassing in summer and fall due to warming and respiration of organic matter (Fig. 3d; DeGrandpre et al., 2002; Shadwick et al., 2010; Signorini et al., 2013; Vandemark et al., 2011; Wang et al., 2013). South of Cape Hatteras, seasonal phytoplankton blooms do not occur regularly and biologically driven $\mathrm{CO}_{2}$ uptake is less pronounced than that further north (Fig. 3e; Reimer et al., 2017; Wang et al., 2013), although sporadic phytoplankton blooms do occur because of intrusions of high-nutrient subsurface Gulf Stream water (Wang et al., 2005, 2013). The influence of riverine inputs is small and localized in the SAB (Cai and Wang, 1998; Wang and Cai, 2004; Wang et al., 2005; L. Xue et al., 2016; Reimer et al., 2017). An exception to this northsouth importance in riverine input is the GOM, where riverine inputs of carbon and nutrients are relatively small. Nevertheless, even here, these inputs can cause local phytoplankton blooms, $\mathrm{CO}_{2}$ drawdown, and low-pH conditions (Salisbury et al., 2008, 2009).
Regional biogeochemical models reproduce the largescale patterns of air-sea $\mathrm{CO}_{2}$ flux with oceanic uptake increasing from the SAB to the GOM (Cahill et al., 2016; Fennel et al., 2008; Previdi et al., 2009). These model studies elucidate the magnitude and sources of interannual variability as well as long-term trends in air-sea $\mathrm{CO}_{2}$ fluxes. Previdi et al. (2009) investigated opposite phases of the North Atlantic Oscillation (NAO) and found that the simulated air-sea flux in the MAB and GOM was $25 \%$ lower in a high-NAO year compared to a low-NAO year. In the MAB, the decrease primarily resulted from changes in wind forcing, while in the GOM changes in surface temperature and new production were more important. Cahill et al. (2016) investigated the impact of future climate-driven warming and trends in atmospheric forcing (primarily wind) on air-sea $\mathrm{CO}_{2}$ flux (without considering the atmospheric increase in $\mathrm{CO}_{2}$ ). Their results suggest that warming and changes in atmospheric forcing have modest impacts on air-sea $\mathrm{CO}_{2}$ flux in the MAB and GOM compared to that in the $\mathrm{SAB}$ where surface warming would turn the region from a net sink into a net source of $\mathrm{CO}_{2}$ to the atmosphere if the increase in atmospheric $\mathrm{CO}_{2}$ were ignored. Model studies also illustrate the effects of interactions between biogeochemical transformations in the sediment and the overlying water column on carbon fluxes. For example, Fennel et al. (2008) showed that the effective alkalinity flux resulting from denitrification in sediments of the Atlantic coast reduces the simulated ocean uptake of $\mathrm{CO}_{2}$ by $6 \%$ compared to a simulation without sediment denitrification.

The passive-margin sediments along the Atlantic coast have not been considered an area of significant $\mathrm{CH}_{4}$ release until recently (Brothers et al., 2013; Phrampus and Hornbach, 2012; Skarke et al., 2014). Phrampus and Hornbach (2012) predicted that massive seepage of $\mathrm{CH}_{4}$ from upper-slope sediments is occurring in response to warming of intermediate-depth Gulf Stream waters. Brothers et al. (2013) and Skarke et al. (2014) documented widespread $\mathrm{CH}_{4}$ plumes in the water column and attributed them to gas hydrate degradation. Estimated $\mathrm{CH}_{4}$ efflux from the sediment in this region ranges from $1.5 \times 10^{-5}$ to $1.8 \times 10^{-4} \mathrm{Tg} \mathrm{yr}^{-1}$, and the uncertainty range reflects different assumptions underlying the conversion from $\mathrm{CH}_{4}$ plume observations to seepage rates. The fraction of the released $\mathrm{CH}_{4}$ that escapes to the atmosphere remains uncertain (Phrampus and Hornbach, 2012).

\subsection{Pacific coast}

The North American Pacific coast extends from Panama to the Gulf of Alaska and is an active margin with varying shelf widths (Fig. 1). The continental shelf is narrow along the coasts of California, Oregon, and Washington, of the order of $10 \mathrm{~km}$, but widens significantly in the Gulf of Alaska, where shelves extend up to $200 \mathrm{~km}$ offshore. In the Gulf of Alaska, freshwater and tidal influences strongly affect cross- 

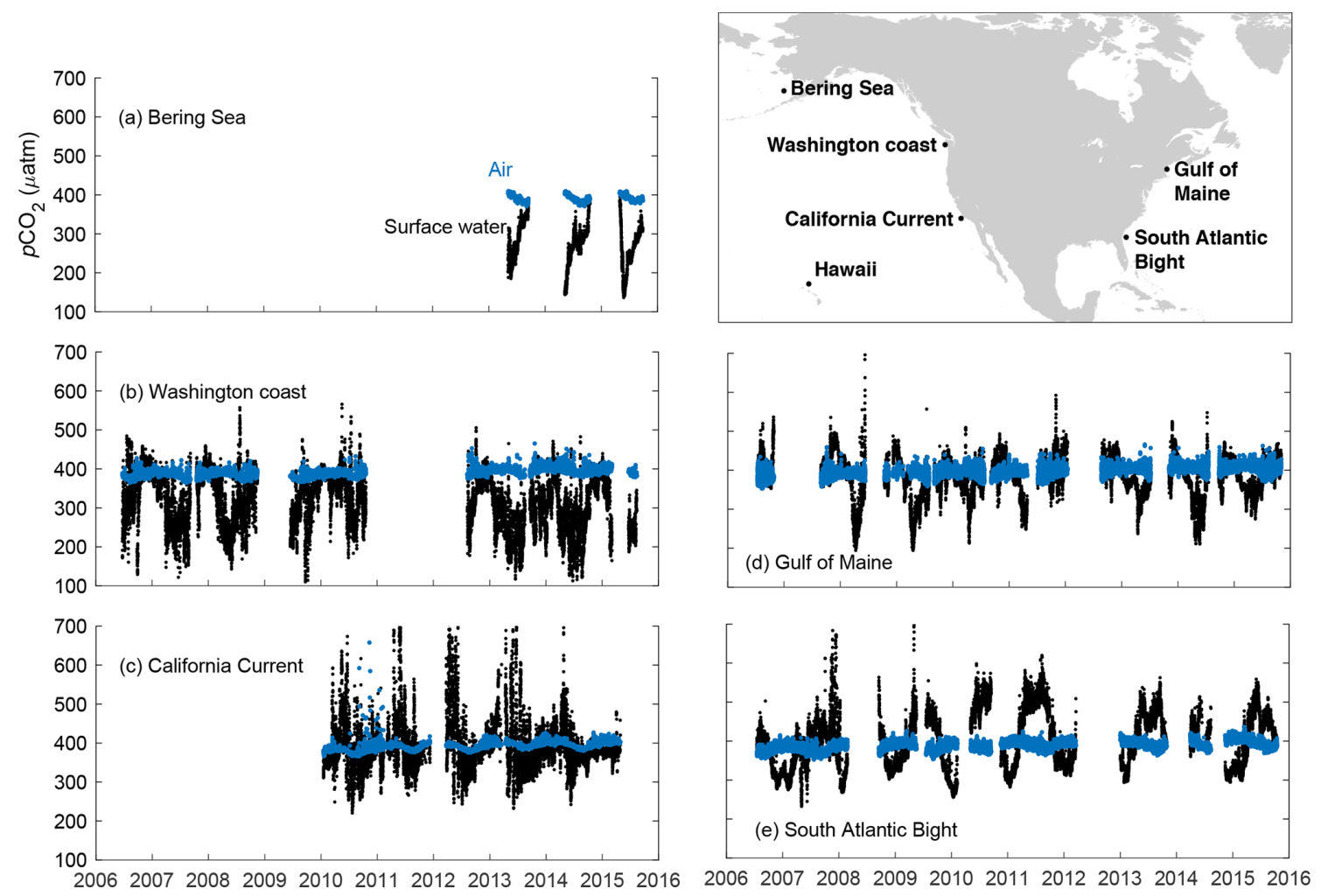

Figure 3. Observations of $p \mathrm{CO}_{2}$ (in $\mu$ atm) in the surface ocean (black) and overlying atmosphere (blue) at five coastal moorings. Map shows mooring locations. Also shown on the map is the location of the Hawaii Ocean Time Series (see Fig. 6). Data sources: Bering Sea (mooring M2; Cross et al., 2014a); Washington coast (Cape Elizabeth mooring; Mathis et al., 2013); California Current (mooring CCE2; Sutton et al., 2012); coastal western Gulf of Maine mooring (Sutton et al., 2013); South Atlantic Bight (Gray's Reef mooring; Sutton et al., 2011)

shelf exchange, and the shelf is dominated by a downwelling circulation. The region from Vancouver Island to Baja California is a classic eastern boundary current upwelling region - the California Current System (Chavez et al., 2017; Hickey, 1998). Winds drive a coastal upwelling circulation characterized by equatorward flow in the California Current and by coastal jets and their associated eddies and fronts that extend offshore, particularly off the coasts of Baja California, California, Washington, and Oregon (Huyer, 1983).

The northern California Current System experiences strong freshwater influences and seasonality in wind forcing that diminish toward the south. In addition to the Columbia River and the Fraser River, a variety of small mountainous rivers, with highly variable discharge, supply freshwater. The Central American Isthmus runs from Panama to the southern tip of Baja California and experiences intense and persistent wind events, large eddies, and high waves that combine to produce upwelling and strong nearshore mixing (ChapaBalcorta et al., 2015; Franco et al., 2014). In addition to alongshore winds, strong seasonal wind jets that pass through the Central American cordillera create upwelling hot spots and drive production during boreal winter months in the gulfs of Tehuantepec, Papagayo, and Panama (Walker Brown et al., 2015; Chapa-Balcorta et al., 2015; Chelton et al., 2000a, b; Gaxiola-Castro and Muller-Karger, 1998). The California Current brings water from the North Pacific southward into the southern California and Central American Isthmus regions, while the California Undercurrent transports equatorial waters northward in the subsurface (Hickey, 1998).

The net exchange of $\mathrm{CO}_{2}$ with the atmosphere along the Pacific coast is characterized by strong spatial and temporal variation and reflects complex interactions between the biological uptake of nutrients and degassing of nutrient- and carbon-rich upwelled waters (Fig. 3b, c). A growing number of coastal air-sea flux studies have used extrapolation techniques to estimate fluxes across the coastal oceans on regional to continental scales (Fig. 2). Observation-based studies of air-sea $\mathrm{CO}_{2}$ flux suggest that estimates for the coastal ocean from Baja California to the Gulf of Alaska range from a weak (Coronado-Álvarez et al., 2017) to moderate sink of atmospheric $\mathrm{CO}_{2}$ over this broad longitudinal range. Central California coastal waters have long been understood to have a near-neutral air-sea $\mathrm{CO}_{2}$ exchange because of their large and counterbalancing periods of efflux during upwelling conditions and influx during periods of relaxation and high primary productivity; this pattern is strongly modulated by $\mathrm{El}$ Niño-La Niña conditions (Friederich et al., 2002). 
Hales et al. (2005) used seasonal data to estimate an uptake of $88 \mathrm{~g} \mathrm{C} \mathrm{m}^{-2} \mathrm{yr}^{-1}$ by Oregon coastal waters. In a follow-up analysis with greater temporal coverage, Evans et al. (2011) showed how large flux events can significantly alter the estimation of net exchanges for the Oregon shelf. After capturing a large and short-lived efflux event, their annual estimate was outgassing of $3.1 \pm 82 \mathrm{~g} \mathrm{C} \mathrm{m}^{-2} \mathrm{yr}^{-1}$ for this same region. The disparity illustrates the importance of basing regional flux estimates on observations that are well resolved in time and space. Capitalizing on the increased and more uniform spatiotemporal coverage of satellite data, Hales et al. (2012) estimated an annual mean uptake of $7.9 \mathrm{~g} \mathrm{C} \mathrm{m}^{-2} \mathrm{yr}^{-1}$ between 22 and $50^{\circ} \mathrm{N}$ within $370 \mathrm{~km}$ offshore. The most northern estimates for the Pacific coast by Evans et al. (2012) and Evans and Mathis (2013) are influxes of $26 \mathrm{~g} \mathrm{C} \mathrm{m}^{-2} \mathrm{yr}^{-1}$ for British Columbian coastal waters shoreward of the $500 \mathrm{~m}$ isobath and $18 \mathrm{~g} \mathrm{C} \mathrm{m}^{-2} \mathrm{yr}^{-1}$ for Gulf of Alaska coastal waters shoreward of the $1500 \mathrm{~m}$ isobath.

Models for the upwelling region (Fiechter et al., 2014; Turi et al., 2014) reproduce the pattern of $\mathrm{CO}_{2}$ outgassing nearshore and $\mathrm{CO}_{2}$ uptake further offshore. They also illustrate the intense eddy-driven variability nearshore. Turi et al. (2014) simulate a weak source of $0.6 \pm 2.4 \mathrm{~g} \mathrm{C} \mathrm{m}^{-2} \mathrm{yr}^{-1}$ for the region from 30 to $46^{\circ} \mathrm{N}$ extending $800 \mathrm{~km}$ of shore. In contrast, Hales et al. (2012) reported a sink of $7.9 \mathrm{~g} \mathrm{C} \mathrm{m}^{-2} \mathrm{yr}^{-1}$ based on observations for the same latitudinal band but only extending $370 \mathrm{~km}$ of shore. Fiechter et al. (2014) simulate a source of atmospheric $\mathrm{CO}_{2}$ of $0.6 \mathrm{Tg} \mathrm{C} \mathrm{yr}^{-1}$ for the region from 35 to $45^{\circ} \mathrm{N}$ within $600 \mathrm{~km}$ of shore, also in contrast to the observation-based estimate of a $14 \mathrm{Tg} \mathrm{C} \mathrm{yr}^{-1}$ sink published by Hales et al. (2012). (The estimate of Fiechter et al., 2014, is not included in Fig. 2 because the area-normalized flux is not available from that study.) Both models simulate strong outgassing within the first $100 \mathrm{~km}$ of shore driven by intense upwelling of nutrientand carbon-rich water, which is compensated for by biologically driven $\mathrm{CO}_{2}$ uptake from the atmosphere as upwelled nutrients are consumed by photosynthesis during subsequent offshore advection within several hundreds of kilometers of the coast. The disagreement in mean simulated fluxes between the two models may partly result from different choices of averaging region and period and differences in model forcing, such as the climatological forcing in Turi et al. (2014) versus realistic variability in Fiechter et al. (2014). Notably, observations for the Oregon shelf by Evans et al. (2015a) showed intense summer upwelling that led to strong outgassing with pronounced variability in air-sea fluxes but only weak stimulation of primary production. They hypothesized that nutrient-rich waters might be subducted offshore at convergent surface temperature fronts before nutrients are fully consumed by primary producers.

The cross-shelf exchange of carbon occurs in the California Current System mostly in response to wind-driven circulation and eddies, but river plumes and tides have also been shown to increase offshore transport in the northern part of the system (Barth et al., 2002; Hales et al., 2006). Uncertainties in published estimates are high, ranging from very small (Ianson and Allen, 2002; Pennington et al., 2010) to very high fractions of primary production (Hales et al., 2005; Turi et al., 2014), again as a result of the region's large spatial and temporal variability. Frischknecht et al. (2018) showed that about $30 \%$ of the organic matter produced within $100 \mathrm{~km}$ of shore is laterally advected toward the open ocean.

Less is known about the air-sea flux of $\mathrm{CH}_{4}$ along the Pacific margin. Recent studies inventoried sedimentary sources of $\mathrm{CH}_{4}$ hydrates, derived from terrestrial and coastal primary production, and suggested that extensive deposits along the Cascadia margin are beginning to destabilize because of warming (Hautala et al., 2014; Johnson et al., 2015).

\subsection{Gulf of Mexico}

The Gulf of Mexico is a semi-enclosed marginal sea at the southern coast of the conterminous United States. The passive-margin shelves of its northern portion are relatively wide (up to $250 \mathrm{~km}$ west of Florida) but, in contrast to shelf waters of the Atlantic coast, those of the Gulf of Mexico are not separated from open-ocean waters by shelf-break fronts or currents. Ocean water enters the gulf mainly through the Yucatán Channel, where it forms the northeastward meandering Loop Current, which sheds anticyclonic eddies and exits the gulf through the Florida Straits (Muller-Karger et al., 2015; Rivas et al., 2005). While shelf circulation is primarily influenced by local wind and buoyancy forcing, outer-shelf regions are at times influenced by Loop Current eddies that impinge on and interact with the shelf (Lohrenz and Verity, 2004). Riverine input is substantial in the northern Gulf of Mexico, where the Mississippi-Atchafalaya river system delivers large loads of freshwater, nutrients, and sediments.

Estimates of air-sea $\mathrm{CO}_{2}$ flux are available from observations and model simulations (Fig. 2). Observational estimates indicate that the Gulf of Mexico, as a whole, is a weak net sink of atmospheric $\mathrm{CO}_{2}$ with an annual average of $2.3 \pm 1.0 \mathrm{~g} \mathrm{C} \mathrm{m}^{-2} \mathrm{yr}^{-1}$ (Robbins et al., 2014). Smaller shelf regions within the gulf differ markedly from this mean flux. The West Florida shelf and western gulf shelf act as sources to the atmosphere, with estimated annual average fluxes of $4.4 \pm 1.3$ and $2.2 \pm 0.6 \mathrm{~g} \mathrm{C} \mathrm{m}^{-2} \mathrm{yr}^{-1}$, respectively; the northern gulf acts as a sink, with an estimated flux of $5.3 \pm$ $4.4 \mathrm{~g} \mathrm{C} \mathrm{m}^{-2} \mathrm{yr}^{-1}$, and the Mexican shelf is almost neutral, with an estimated uptake flux of $1.1 \pm 0.6 \mathrm{~g} \mathrm{C} \mathrm{m}^{-2} \mathrm{yr}^{-1}$ (Robbins et al., 2014). A more recent estimate for the west Florida shelf is $4.4 \pm 18.0 \mathrm{~g} \mathrm{C} \mathrm{m}^{-2} \mathrm{yr}^{-1}$ (Robbins et al., 2018). Huang et al. (2015) estimated a larger uptake on the northern gulf shelf of $11 \pm 44 \mathrm{~g} \mathrm{C} \mathrm{m}^{-2} \mathrm{yr}^{-1}$ (i.e., about twice the estimate of Robbins et al., 2014) and reported a much larger uncertainty. In an analysis that combines satellite and in situ observations, Lohrenz et al. (2018) estimated a similar uptake for the northern Gulf of Mexico of $13 \pm 3.6 \mathrm{~g} \mathrm{C} \mathrm{m}^{-2} \mathrm{yr}^{-1}$. The overall air-sea carbon exchanges in the gulf vary signif- 
icantly from year to year because of interannual variability in wind, temperature, and precipitation (Muller-Karger et al., 2015).

Model-simulated air-sea $\mathrm{CO}_{2}$ fluxes by $\mathrm{Z}$. Xue et al. (2016) agree relatively well with the estimates of Robbins et al. (2014), reproducing the same spatial pattern though their simulated gulf-wide uptake of $8.5 \pm 6.5 \mathrm{~g} \mathrm{C} \mathrm{m}^{-2} \mathrm{yr}^{-1}$ is larger. This discrepancy results largely from a greater simulated sink in the open gulf. Also, the uncertainty estimates of the model-simulated fluxes by Z. Xue et al. (2016) are much larger than those of Robbins et al. (2014); the latter might be too optimistic in reporting uncertainties of the flux estimates. Overall, the various observation- and model-derived estimates for gulf regions agree in terms of their broad patterns, but existing discrepancies and, at times, large uncertainties indicate that current estimates need further refinement.

The quantitative understanding of $\mathrm{CH}_{4}$ dynamics in coastal and oceanic environments of the Gulf of Mexico is limited. Solomon et al. (2009) speculated that deep $\mathrm{CH}_{4}$ hydrate seeps in the gulf are a potentially significant $\mathrm{CH}_{4}$ source to the atmosphere. They estimated oceanatmosphere fluxes from seep plumes of $1150 \pm 790$ to $38000 \pm 21000 \mathrm{~g} \mathrm{CH}_{4} \mathrm{~m}^{-2} \mathrm{~d}^{-1}$ compared with $2.2 \pm 2.0$ to $41 \pm 8.2 \mathrm{~g} \mathrm{CH}_{4} \mathrm{~m}^{-2} \mathrm{~d}^{-1}$ for background sites. Subsequent acoustic analyses of bubble plume characteristics question the finding that $\mathrm{CH}_{4}$ bubbles make their way to the surface (Weber et al., 2014), and the fate of $\mathrm{CH}_{4}$ emissions from seeps and their overall contribution to atmospheric $\mathrm{CH}_{4}$ remain uncertain.

\subsection{Arctic coast}

The North American Arctic coastal ocean comprises broad $(\sim 300 \mathrm{~km})$ shallow shelves in the Bering and Chukchi seas, the narrower $(<100 \mathrm{~km})$ Beaufort Sea shelf, Hudson Bay, and the extensive Canadian Arctic shelf (Fig. 1). Shelf water enters these regions from the North Pacific through the Bering Strait and follows a large-scale pathway via the Chukchi and Beaufort seas onto the Canadian Arctic shelf and, ultimately, the North Atlantic (Carmack et al., 2006, 2015). Hudson Bay receives significant inputs of freshwater (Déry et al., 2005). Except for the southernmost Bering Sea, most of the coastal Arctic is covered with sea ice from about October to June. Areas of persistent multiyear sea ice at the northernmost extent of the Canadian Arctic shelf are rapidly declining (Stroeve et al., 2012).

Coastal waters in the Arctic have been consistently described as a net sink for atmospheric $\mathrm{CO}_{2}$ (Fig. 2). An observation-based estimate for uptake in the Bering Sea is $9.6 \mathrm{~g} \mathrm{C} \mathrm{m}^{-2} \mathrm{yr}^{-1}$ by Cross et al. (2014b). Estimates for the Chuckchi Sea range from $15 \mathrm{~g} \mathrm{C} \mathrm{m}^{-2} \mathrm{yr}^{-1}$ (Evans et al., $2015 \mathrm{~b}$ ) to $175 \pm 44 \mathrm{~g} \mathrm{C} \mathrm{m}^{-2} \mathrm{yr}^{-1}$ (Bates, 2006). For the Beaufort Sea, estimates range from $4.4 \mathrm{~g} \mathrm{C} \mathrm{m}^{-2} \mathrm{yr}^{-1}$ (Evans et al., 2015b) to $44 \pm 28 \mathrm{~g} \mathrm{C} \mathrm{m}^{-2} \mathrm{yr}^{-1}$ (Else et al., 2013).
In Hudson Bay, Else et al. (2008) estimated an uptake of $3.2 \pm 1.8 \mathrm{~g} \mathrm{C} \mathrm{m}^{-2} \mathrm{yr}^{-1}$. The consistently observed uptake is thought to be caused by low surface water $p \mathrm{CO}_{2}$ relative to the atmosphere during ice-free months (see, e.g., Fig. 3a). These low levels are set by a combination of low water temperatures and seasonally high rates of both ice-associated and open-water primary production (Cai et al., 2010a, 2014; Steiner et al., 2014), as well as by limited gas exchange through sea ice relative to open water during winter (Butterworth and Miller, 2016; van der Loeff et al., 2014).

In recent years, sea ice growth and decay has been shown to significantly affect the air-sea $\mathrm{CO}_{2}$ flux (Rysgaard et al., 2007, 2009). During sea ice formation, brine rejection forms dense high-saline water that is enriched in DIC relative to alkalinity (Dieckmann et al., 2008; Rysgaard et al., 2013). During sea ice decay, an excess of alkalinity relative to DIC is released in meltwater. The sinking of dense, carbon-rich brine provides a pathway for carbon sequestration as suggested by Rysgaard et al. (2013), although modeling studies suggest that carbon export through this process is relatively small (Moreau et al., 2016, 2015).

With regard to Arctic $\mathrm{CH}_{4}$ fluxes, much more is known about the emission potential, distribution, and functioning of terrestrial sources (McGuire et al., 2009); knowledge of marine $\mathrm{CH}_{4}$ sources is developing slowly due to sparse observations and the logistical challenges of Arctic marine research. The largest marine $\mathrm{CH}_{4}$ source in the Arctic is the dissociation of gas hydrates stored in continental margin sediments (Parmentier et al., 2013). As sea ice cover continues to retreat and ocean waters warm, $\mathrm{CH}_{4}$ hydrate stability is expected to decrease with potentially large and long-term implications. An additional potential marine $\mathrm{CH}_{4}$ source, unique to polar settings, is release from subsea permafrost layers, with fluxes from thawed sediments reported to be orders of magnitude higher than fluxes from adjacent frozen sediments (Shakhova et al., 2015).

\subsection{Summary estimate of $\mathrm{CO}_{2}$ uptake and a carbon budget for the North American EEZ}

Despite the variability in regional estimates discussed above and summarized in Fig. 2 and Table S1, North American coastal waters clearly act as a net sink of atmospheric carbon. However, because of the local footprint of some studies, discrepancies in temporal and spatial coverage among studies, and gaps in space and time, it is difficult to combine these various regional estimates into one summary estimate of $\mathrm{CO}_{2}$ uptake for the North American EEZ with any confidence. In order to arrive at such a summary estimate, we draw on the regional information compiled in the previous sections in combination with two global approaches: the observation-based synthesis of Laruelle et al. (2014) and the process-based global model of Bourgeois et al. (2016).

First, we compare estimates from the two global approaches, which are available for a global segmentation of 
Table 1. Regional estimates of net air-sea $\mathrm{CO}_{2}$ flux from a global data synthesis and a global biogeochemical model for the MARgins and CATchments Segmentation (MARCATS) regions. MARCATS segments are named as follows: (1) northeastern Pacific, (2) California Current, (3) eastern tropical Pacific, (9) Gulf of Mexico, (10) Florida upwelling, (11) Labrador Sea, (12) Hudson Bay, (13) Canadian Arctic Archipelago. Positive numbers indicate a flux to the atmosphere; $1 \mathrm{Tg}=10^{12} \mathrm{~g}$.

\begin{tabular}{lrrr|rr}
\hline Segment no. & Area & \multicolumn{2}{c|}{ Laruelle et al. (2014) } & \multicolumn{2}{c}{ Bourgeois et al. (2016) } \\
\cline { 2 - 6 } & $\left(10^{3} \mathrm{~km}^{2}\right)$ & $\mathrm{g} \mathrm{C} \mathrm{m}^{-2} \mathrm{yr}^{-1}$ & $\mathrm{Tg} \mathrm{C} \mathrm{yr}^{-1}$ & $\mathrm{~g} \mathrm{C} \mathrm{m}^{-2} \mathrm{yr}^{-1}$ & $\mathrm{Tg} \mathrm{C} \mathrm{yr}^{-1}$ \\
\hline 1 & 460 & -15 & -6.8 & -22 & -10 \\
2 & 210 & -0.62 & -0.13 & -2.3 & -0.48 \\
3 & 200 & 0.95 & 0.19 & -1.1 & -0.22 \\
9 & 540 & -3.9 & -2.1 & -8.3 & -4.5 \\
10 & 860 & -3.1 & -2.7 & -17 & -15 \\
11 & 400 & -47 & -19 & -22 & -8.8 \\
12 & 1100 & $\mathrm{NA}$ & $\mathrm{NA}$ & -3.4 & -3.8 \\
13 & 1200 & -12 & -14 & -5.2 & -6.2 \\
\hline Total & 4900 & -9.0 & -44 & -10 & -49 \\
\hline
\end{tabular}

the coastal zone and associated watersheds known as MARCATS (MARgins and CATchments Segmentation; Laruelle et al., 2013). At a resolution of $0.5^{\circ}$, MARCATS delineates a total of 45 coastal segments, eight of which surround North American. Laruelle et al. (2014) analyzed the Surface Ocean $\mathrm{CO}_{2}$ Atlas 2.0 database (Bakker et al., 2014) and estimated an uptake in the North American MARCATS, excluding Hudson Bay, of $44.5 \mathrm{Tg} \mathrm{C} \mathrm{yr}^{-1}$ (Table 1). The processbased model of Bourgeois et al. (2016) simulated an uptake of 48.8 $\mathrm{TgC} \mathrm{yr}^{-1}$, or 45.0 $\mathrm{Tg} \mathrm{C} \mathrm{yr}^{-1}$ when excluding Hudson Bay (Table 1). Although there are significant regional discrepancies between the two estimates for the eastern tropical Pacific Ocean, the Gulf of Mexico, the Florida upwelling region (actually covering the eastern United States including the SAB, MAB, and GOM), the Labrador Sea, and the Canadian Arctic shelf, the total flux estimates for North America are in close agreement. This builds some confidence in the global model estimates.

Next, we use the global model to obtain $\mathrm{CO}_{2}$ flux estimates for the North American EEZ in a finer-grained decomposition (Fig. 4, Table 2). First, we compare the regional area-specific flux estimates from Fig. 2 and Table 2 with the global model (see Fig. 4a, b, d). For the Atlantic coast there is excellent agreement for the SAB, but the global model simulates a higher $\mathrm{CO}_{2}$ uptake than the regional studies in the MAB, GOM, and the Scotian Shelf. This discrepancy is likely due to the fact that the global model is too coarse to accurately simulate the shelf-break current systems and thus significantly underestimates the water residence times on the shelf (Rutherford and Fennel, 2018). No regional estimates are available for the Gulf of St. Lawrence. For the Pacific coast and the Gulf of Mexico, the global model's estimates are within the range of available regional estimates for the Gulf of Alaska, the northern California Current System, and the Gulf of Mexico. In the central and southern California Current System, the model favors outgassing more than in the regional estimates. In the sub-Arctic and Arctic regions, the global model's estimates are smaller than the regional ones for the Beaufort and Chukchi seas and Hudson Bay, but they are similar for the Bering Sea. No regional estimates are available for the Canadian Arctic shelf and Labrador shelf.

Conversion of the area-specific fluxes to total fluxes (see Fig. 4c, e) shows that the Labrador shelf, Gulf of Alaska, and Bering Sea are the biggest contributors to the total flux in the North American EEZ in the global model. For the Labrador shelf, the region with the largest flux estimate, there are no regional estimates available. For the two next largest, the Gulf of Alaska and the Bering Sea, the global model agrees well with the regional estimates. Thus, despite some regional discrepancies, it seems justifiable to use the global model estimates for a North American coastal carbon budget. The model simulates a net uptake of $\mathrm{CO}_{2}$ in the North American EEZ (excluding the EEZ of the Hawaiian and other islands) of $160 \mathrm{Tg} \mathrm{Cyr}^{-1}$ with an anthropogenic flux contribution of $59{\mathrm{TgC} \mathrm{yr}^{-1}}^{-1}$. The three biggest contributors (LS,

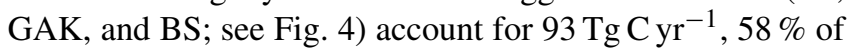
the total uptake, with an anthropogenic flux contribution of $26 \mathrm{TgC} \mathrm{yr}^{-1}$, while making up only $29 \%$ of the combined EEZ area. These three regions have a large contribution because they are characterized by large area-specific fluxes and they are vast. The global model also estimates large fluxes for the MAB, GOM, and SS, which are probably overestimates, but these regions are significantly smaller and thus contribute much less $\left(28 \mathrm{Tg} \mathrm{C} \mathrm{yr}^{-1}\right)$ to the overall flux estimate. When dividing the North American EEZ into the Arctic and subArctic (GAK, BS, BCS, CAS, HB, LS), mid-latitude Atlantic (GMx, SAB, MAB, GOM, SS, GStL), and mid-latitude Pacific (CCN, CCC, CCS, Isthmus), their relative flux contributions are 104,62 , and $-3.7 \mathrm{Tg} \mathrm{C} \mathrm{yr}^{-1}$, respectively, with area contributions of $51 \%, 25 \%$, and $24 \%$ to the total area of the North American EEZ, respectively. 

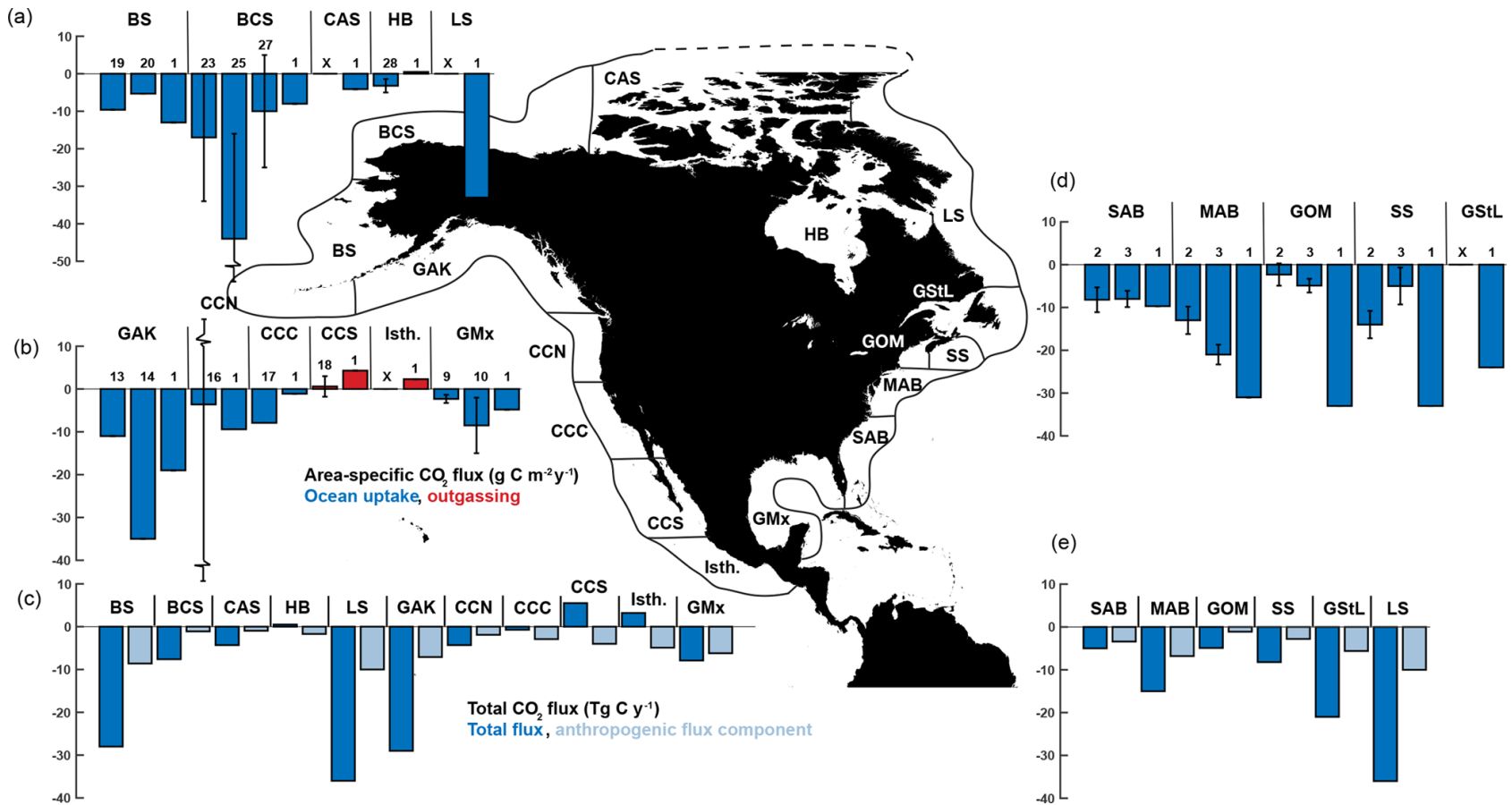

Figure 4. North American continent with EEZ decomposition (indicated by black outlines). Selected area-specific regional $\mathrm{CO}_{2}$ flux estimates from Fig. 2 are shown in comparison to the global model estimates (referred to as 1) in (a, b, d) (see Fig. 2 for reference key). "X" indicates that no regional estimate is available. Total $\mathrm{CO}_{2}$ flux estimates from the global model and the anthropogenic components are shown in (c, e). Subregion abbreviations are MAB - Mid-Atlantic Bight, GOM - Gulf of Maine, SS - Scotian Shelf, GStL - Gulf of St. Lawrence and Grand Banks, LS - Labrador shelf, HB - Hudson Bay, CAS - Canadian Arctic shelf, BCS - Beaufort and Chukchi seas, BS - Bering Sea, GAK - Gulf of Alaska, NCCS - northern California Current System, CCCS - central California Current System, SCCS - southern California Current System, Isthmus - American isthmus, GMx - Gulf of Mexico and Yucatán Peninsula, SAB - South Atlantic Bight.

Next, we construct a carbon budget for the North American EEZ by combining the atmospheric $\mathrm{CO}_{2}$ uptake estimate with estimates of carbon transport from land and carbon burial in ocean sediments. We assume $160 \mathrm{Tg} \mathrm{Cyr}^{-1}$ as the best estimate of net uptake by coastal waters of North America, excluding tidal wetlands and estuaries. Unfortunately, there are no formal error estimates for this uptake. Instead, we estimate an error by first noting that the Bourgeois et al. (2016) model is in good agreement with the observationbased estimates for the MARCATS regions of North America; furthermore, the error estimate for the uptake by continental shelves globally is about $25 \%$, with the North American MARCATS regions having mainly "fair" data quality (Laruelle et al., 2014). Hence, assuming an error of $\pm 50 \%$ for the uptake by North American EEZ waters seems reasonable.

Carbon delivery to the coastal ocean from land via rivers and from tidal wetlands after estuarine processing (i.e., $\mathrm{CO}_{2}$ outgassing and carbon burial in estuaries) is estimated to be $106 \pm 30 \mathrm{Tg} \mathrm{C} \mathrm{yr}^{-1}$ (Windham-Myers et al., 2018). Estimates of carbon burial, based on the method of Dunne et al. (2007) for the regional decomposition of the North American EEZ, are reported in Table 2, with a total flux of $120 \mathrm{Tg} \mathrm{C} \mathrm{yr}^{-1}$. We consider these fluxes to be an upper bound because they are substantially larger than other estimates. The Dunne et al. (2007) global estimates of organic carbon burial in waters shallower than $2000 \mathrm{~m}$ are $19 \pm 9 \mathrm{~g} \mathrm{C} \mathrm{m}^{-2} \mathrm{yr}^{-1}$, much larger than the estimates of 6 and $1 \mathrm{~g} \mathrm{C} \mathrm{m}^{-2} \mathrm{yr}^{-1}$ by Chen (2004) and Muller-Karger et al. (2005), respectively, although the areas are slightly different in the three studies. The organic carbon burial estimates of Dunne et al. (2007) for the GOM, $\mathrm{MAB}$, and SAB (Table 2) are larger by factors of 8, 17, and 3 , respectively, than the best estimates of the empirical model of Najjar et al. (2018). However, due to different definitions of the boundary between coastal waters and the open ocean, the combined area of the GOM, MAB, and SAB in Najjar et al. (2018) is about a third of that of Dunne et al. (2007). Finally, Dunne et al. (2007) estimated the organic carbon burial in Hudson Bay to be $19 \mathrm{~g} \mathrm{C} \mathrm{m}^{-2} \mathrm{yr}^{-1}$ compared to a mean estimate of $1.5 \pm 0.7 \mathrm{~g} \mathrm{C} \mathrm{m}^{-2} \mathrm{yr}^{-1}$ of burial from sediment cores (Kuzyk et al., 2009). Given these results, we consider the estimates of Dunne et al. (2007) to be an upper bound and assume that a reasonable lower bound is about an order of magnitude smaller, thus placing the organic carbon burial

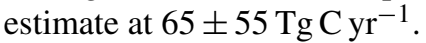

If these estimates of net air-sea flux, carbon burial, and carbon input from land are accurate, then the residual must be balanced by an increase in carbon inventory in coastal wa- 


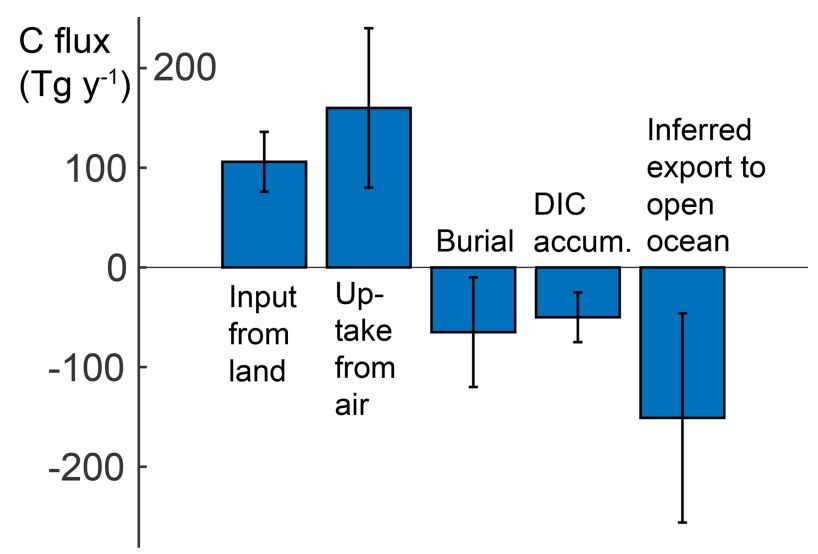

Figure 5. Carbon budget for the EEZ of the USA, Canada, and Mexico excluding the EEZs of Hawaii and other islands. Here positive fluxes are a source to the coastal ocean. The accumulation of DIC in EEZ waters is reported with a negative sign to illustrate that all fluxes balance.

ters and a net transfer of carbon from coastal to open-ocean waters (Fig. 5). The rate of carbon accumulation in the North American EEZ from the model of Bourgeois et al. (2016) is $50 \mathrm{Tg} \mathrm{Cyr}^{-1}$ (Fig. 5). Here again, we assume an uncertainty of $\pm 50 \%$. The residual of $151 \pm 105 \mathrm{Tg} \mathrm{C} \mathrm{yr}^{-1}$ is the inferred export of carbon to the open ocean (Fig. 5). The fact that the error in this residual is large in absolute and relative terms emphasizes the need for more accurate quantification of the terms in the coastal carbon budget. The challenge, however, is that many of these terms are small compared to internal carbon cycling in coastal waters, which is dominated by primary production and decomposition. Two separate estimates of primary production (Table 2) are in broad agreement and reveal that the fluxes in Fig. 5 (of the order of 10 to

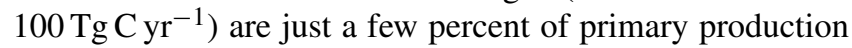
(of the order of $1000 \mathrm{Tg} \mathrm{Cyr}^{-1}$; see total in Table 2). This also indicates that small changes in carbon cycling in coastal waters can result in large changes in atmospheric uptake and transport to the open ocean.

\section{Trends in carbon fluxes and acidification in North American coastal waters}

\subsection{Carbon flux trends}

Two important open questions remain: how will the coastal ocean $\mathrm{CO}_{2}$ sink and its anthropogenic flux component change in the future? And how will changing climate and other forcings affect the total and anthropogenic flux proportions? As stated in Sect. 2, when considering the ocean's role in sequestering anthropogenic carbon, the most relevant component is anthropogenic flux, not the total uptake flux. Neither quantifying the anthropogenic carbon flux component nor predicting its future trend is straightforward. Here we only describe the factors likely to result in trends in total carbon fluxes, but changes in total carbon fluxes suggest changes in anthropogenic fluxes as well.

A direct effect of increasing atmospheric $\mathrm{CO}_{2}$ will be an increase in net uptake by the coastal ocean, but this is tempered by a decrease in the ocean's buffer capacity as DIC increases. More indirect effects include changes in climate forcings (i.e., surface heat fluxes, winds, and freshwater input).

Ocean warming reduces the solubility of gases and thus directly affects gas concentrations near the surface; this will likely decrease the net air-sea flux of $\mathrm{CO}_{2}$ by reducing the undersaturation of $\mathrm{CO}_{2}$ (see Cahill et al., 2016, for the North American Atlantic coast). Surface warming may also strengthen vertical stratification and thus impede vertical mixing, which will affect the upward diffusion of nutrients and DIC. Enhanced stratification could therefore lead to decreases in both biologically driven carbon uptake and $\mathrm{CO}_{2}$ outgassing. However, model projections for the northern Gulf of Mexico show that the direct effect of increasing atmospheric $\mathrm{CO}_{2}$ overwhelms the other more secondary effects (Laurent et al., 2018). Along the Pacific coast, surface warming will increase the horizontal gradient between cold, freshly upwelled source waters and warm, offshore surface water, leading to a greater tendency for the subduction of upwelled water at offshore surface temperature fronts during periods of persistent and strong upwelling-favorable winds. The cumulative effect of these processes for the $\mathrm{Pa}$ cific coast may be greater and more persistent $\mathrm{CO}_{2}$ outgassing nearshore and lower productivity offshore as upwelled nitrate is exported before it can be used by the phytoplankton community (Evans et al., 2015a). In the Arctic, warming leads to reductions in ice cover, which increases air-sea gas exchange (Bates and Mathis, 2009), and the melting of permafrost, which leads to the release of large quantities of $\mathrm{CH}_{4}$ to the atmosphere, from both the land surface and the coastal ocean (Crabeck et al., 2014; Parmentier et al., 2013).

Changes in wind stress directly affect air-sea $\mathrm{CO}_{2}$ fluxes via the gas transfer velocity, which is a function of wind speed, but also indirectly through changes in ocean circulation (Bakun, 1990). For the North American Atlantic coast, changes in wind stress were shown to significantly modify air-sea fluxes (Wanninkhof and Trinanes, 2017; Cahill et al., 2016; Previdi et al., 2009). Along the North American Pacific coast, upwelling-favorable winds have intensified in recent years, especially in the northern parts of the upwelling regimes (García-Reyes et al., 2015; Rykaczewski and Checkley, 2008; Rykaczewski et al., 2015; Sydeman et al., 2014). This has led to a shoaling of nutrient-rich subsurface waters (Aksnesa and Ohman, 2009; Bograd et al., 2015), increased productivity (Chavez et al., 2011, 2017; Jacox et al., 2015; Kahru et al., 2015), higher DIC delivery to the surface (Turi et al., 2016), and declining oxygen levels (Crawford and Peña, 2016; Peterson et al., 2013; Bograd et al., 2015). 
Table 2. Estimates of satellite-derived carbon burial and primary production (NPP) from Dunne et al. (2007) and model-simulated NPP and air-sea $\mathrm{CO}_{2}$ flux from Bourgeois et al. (2016) for a decomposition of the EEZ of Canada, the US, and Mexico. Model estimates are calculated by averaging the years 1993-2012. Positive numbers represent fluxes into the coastal ocean. Subregion abbreviations are given in the caption of Fig. 4.

\begin{tabular}{|c|c|c|c|c|c|c|c|c|}
\hline \multirow{2}{*}{$\begin{array}{l}\text { EEZ region, area } \\
10^{3} \mathrm{~km}^{2}\end{array}$} & \multicolumn{2}{|c|}{$\mathrm{C}$ burial } & \multicolumn{2}{|c|}{ Satellite NPP } & \multicolumn{2}{|c|}{ Model NPP } & \multicolumn{2}{|c|}{$\begin{array}{l}\text { Model air-sea } \mathrm{CO}_{2} \text { flux } \\
\text { (anthropogenic fraction) }\end{array}$} \\
\hline & $\mathrm{g} \mathrm{Cm}^{-2} \mathrm{yr}^{-1}$ & $\operatorname{TgC} \mathrm{yr}^{-1}$ & $\mathrm{~g} \mathrm{Cm}^{-2} \mathrm{yr}^{-1}$ & $\operatorname{TgC~} \mathrm{yr}^{-1}$ & $\mathrm{~g} \mathrm{Cm}^{-2} \mathrm{yr}^{-1}$ & $\operatorname{Tg} C \mathrm{yr}^{-1}$ & $\mathrm{~g} \mathrm{Cm}^{-2} \mathrm{yr}^{-1}$ & $\operatorname{TgC~} \mathrm{yr}^{-1}$ \\
\hline MAB, 500 & 23 & 101 & 360 & 170 & 260 & 120 & $31(14)$ & $15(6.8)$ \\
\hline GOM, 160 & 46 & 5.5 & 490 & 58 & 180 & 26 & $33(7.1)$ & $4.9(1.1)$ \\
\hline SS, 220 & 9.8 & 2.0 & 300 & 63 & 170 & 43 & $33(11)$ & $8.2(2.8)$ \\
\hline GStL, 860 & 16 & 11 & 260 & 190 & 150 & 130 & $24(6.5)$ & $21(5.6)$ \\
\hline LS, 1100 & 2.3 & 2.3 & 120 & 120 & 82 & 88 & $33(9.5)$ & $36(10)$ \\
\hline $\mathrm{HB}, 1200$ & 19 & 17.1 & 144 & 130 & 130 & 150 & $-0.48(1.4)$ & $-0.50(1.7)$ \\
\hline CAS, 1000 & 2.6 & 1.6 & 42 & 26 & 19 & 20 & $4.1(0.96)$ & $4.3(0.96)$ \\
\hline BCS, 950 & 12 & 10 & 120 & 110 & 49 & 47 & $8.0(1.2)$ & $7.6(1.1)$ \\
\hline BS, 2200 & 17 & 34 & 240 & 490 & 130 & 270 & $13(4.0)$ & $28(8.6)$ \\
\hline GAK, 1500 & 7.2 & 10.0 & 260 & 360 & 130 & 210 & $19(4.6)$ & $29(7.1)$ \\
\hline CCSN, 460 & 6.1 & 2.54 & 270 & 110 & 160 & 73 & $9.4(4.2)$ & 4.3 (1.9) \\
\hline CCSC, 640 & 1.2 & 0.65 & 260 & 150 & 170 & 110 & $1.1(4.4)$ & $0.72(2.9)$ \\
\hline CCSS, 1200 & 0.99 & 1.1 & 210 & 230 & 150 & 190 & $-4.3(3.1)$ & $-5.5(4.0)$ \\
\hline Isthmus, 1400 & 0.42 & 0.53 & 230 & 300 & 150 & 200 & $-2.3(3.6)$ & $-3.2(4.9)$ \\
\hline GMx, 1600 & 6.2 & 8.7 & 250 & 350 & 220 & 360 & $4.8(3.7)$ & $7.9(6.2)$ \\
\hline $\mathrm{SAB}, 500$ & 5.4 & 2.4 & 210 & 92 & 260 & 130 & $9.7(6.6)$ & $5.0(3.4)$ \\
\hline Islands, 7500 & 0.0055 & 0.041 & 120 & 890 & 80 & 620 & $-1.4(4.1)$ & $-11(31)$ \\
\hline Total & - & 120 & - & 3400 & - & 2800 & - & $150(100)$ \\
\hline Total without islands & - & 120 & - & 2500 & - & 2200 & - & $160(59)$ \\
\hline
\end{tabular}

In the coastal Arctic, late-season air-sea $\mathrm{CO}_{2}$ fluxes may become increasingly directed toward the atmosphere as Arctic low-pressure systems with storm-force winds occur more often over open water, thus ventilating $\mathrm{CO}_{2}$ respired from the high organic carbon loading of the shallow shelf (Evans et al., 2015b; Hauri et al., 2013; Steiner et al., 2013).

In a study that directly assesses changes in coastal carbon uptake, Laruelle et al. (2018) investigated trends in the airsea $p \mathrm{CO}_{2}$ gradient $\left(\Delta p \mathrm{CO}_{2}=\right.$ atmospheric $p \mathrm{CO}_{2}$ - ocean $p \mathrm{CO}_{2}$ ), which imply a strengthening or weakening of the net $\mathrm{CO}_{2}$ uptake by shelf systems. An increasing $\Delta p \mathrm{CO}_{2}$ implies that ocean $p \mathrm{CO}_{2}$ rises more slowly than atmospheric $p \mathrm{CO}_{2}$ and corresponds to increased net uptake and potentially increased cross-shelf export. In their observation-based analysis of decadal trends in shelf $p \mathrm{CO}_{2}$, Laruelle et al. (2018) found that coastal waters lag compared to the rise in atmospheric $\mathrm{CO}_{2}$ in most regions. In the MAB, the Labrador shelf, the Vancouver shelf, and the $\mathrm{SAB}, \Delta p \mathrm{CO}_{2}$ has increased by $1.9 \pm 3.1,0.68 \pm 0.61,0.83 \pm 1.7$, and $0.51 \pm 0.74 \mu \mathrm{atm} \mathrm{yr}^{-1}$, respectively, implying that surface ocean $p \mathrm{CO}_{2}$ does not increase or increases at a slower rate than atmospheric $\mathrm{CO}_{2}$. The only North American coastal region that exhibits a negative trend is the Bering Sea, with $-1.1 \pm 0.74 \mu \mathrm{atm} \mathrm{yr}^{-1}$, meaning that surface ocean $p \mathrm{CO}_{2}$ increases at a faster rate than in the atmosphere. Laruelle et al. (2018) concluded that the lag in coastal ocean $p \mathrm{CO}_{2}$ increase compared to that in the atmosphere in most regions indicates an enhancement in

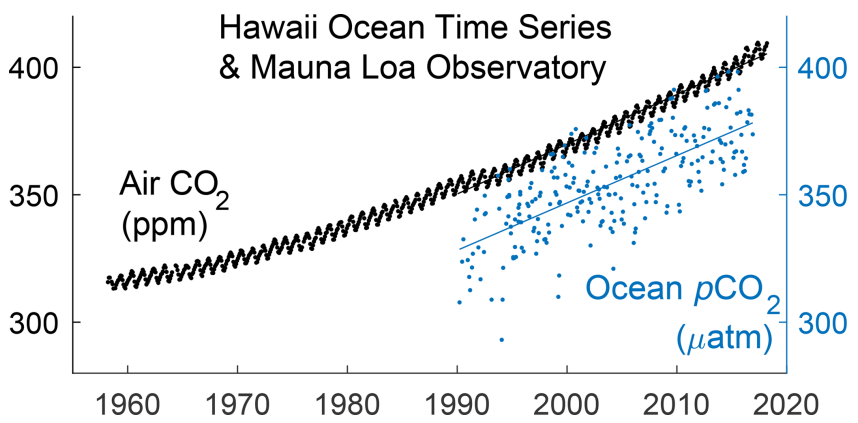

Figure 6. Atmospheric $\mathrm{CO}_{2}$ (black dots) measured at the Mauna Loa Observatory in Hawaii beginning in 1958 and surface ocean $p \mathrm{CO}_{2}$ data (blue dots) from the Hawaii Ocean Time Series (HOT) station (see Fig. 3 for site location). Black and blue lines indicate linear trends after 1990. Atmospheric $\mathrm{CO}_{2}$ increased by $1.86 \pm 0.11 \mathrm{ppm} \mathrm{yr}^{-1}$. Surface ocean $p \mathrm{CO}_{2}$ increased by $1.95 \pm 0.017 \mu \mathrm{atm} \mathrm{yr}^{-1} . p \mathrm{CO}_{2}$ is calculated using CO2SYS, with Mehrbach refit coefficients for the dissociation constants of $\mathrm{H}_{2} \mathrm{CO}_{3}$ and $\mathrm{HCO}_{3}^{-}$, and Dickson's dissociation constant for $\mathrm{HSO}_{4}^{-}$. Data sources: Mauna Loa (http://www.esrl.noaa.gov/gmd/ccgg/trends/ data.html, last access: 1 May 2018); HOT (http://hahana.soest. hawaii.edu/hot/hot-dogs/interface.html, last access: 1 May 2018).

the coastal uptake and export of atmospheric $\mathrm{CO}_{2}$, although they did not investigate alternative explanations. 


\subsection{Acidification trends}

Increasing atmospheric $\mathrm{CO}_{2}$ emissions lead to rising atmospheric $\mathrm{CO}_{2}$ levels (Fig. 6) and a net ocean uptake of $\mathrm{CO}_{2}$. Since about 1750 , the ocean has absorbed $27 \%$ of anthropogenic $\mathrm{CO}_{2}$ emissions to the atmosphere from fossil fuel burning, cement production, and land-use changes (Canadell et al., 2007; Le Quéré et al., 2015; Sabine and Tanhua, 2010). As a result of this uptake, the surface ocean $p \mathrm{CO}_{2}$ has increased (Fig. 6) and oceanic pH, carbonate ion concentration, and carbonate saturation state have decreased (Caldeira and Wickett, 2003; Feely et al., 2004, 2009; Orr et al., 2005). Commonly called "ocean acidification", this suite of chemical changes is defined more precisely as "any reduction in the $\mathrm{pH}$ of the ocean over an extended period, typically decades or longer, which is caused primarily by uptake of $\mathrm{CO}_{2}$ from the atmosphere but can also be caused by other chemical additions or subtractions from the ocean" (IPCC, 2011 , p. 37). In addition to the uptake of $\mathrm{CO}_{2}$ from the atmosphere, variations in DIC concentrations and thus $\mathrm{pH}$ can be caused by ocean transport processes and biological production and respiration. Ocean acidification can significantly affect the growth, metabolism, and life cycles of marine organisms (Fabry et al., 2008; Gattuso and Hansson, 2011; Somero et al., 2015) and most directly affects marine calcifiers, organisms that precipitate $\mathrm{CaCO}_{3}$ to form internal or external body structures. When the carbonate saturation state decreases below the equilibrium point for carbonate precipitation-dissolution, conditions are said to be corrosive, or damaging, to marine calcifiers. Ocean acidification makes it more difficult for calcifying organisms to form shells or skeletons, perform metabolic functions, and survive. Early life stages are particularly vulnerable as shown by recent large-scale die-offs of oyster larvae in the coastal Pacific where increased energetic expenses under low $\mathrm{pH}$ have led to compromised development of essential functions and insufficient initial shell formation (Waldbusser et al., 2015).

Acidification trends in open-ocean surface waters tend to occur at a rate that is commensurate with the rate of the increase in atmospheric $\mathrm{CO}_{2}$ (see trends of atmospheric $\mathrm{CO}_{2}$ in comparison to surface ocean $p \mathrm{CO}_{2}$ from the Hawaii Ocean Time Series in Fig. 6). Acidification in coastal waters is more variable and often event-driven because coastal waters have greater seasonality (Fig. 3) and are more susceptible to changes in circulation, such as upwelling. Along the Pacific coast, climate-driven changes in upwelling circulation result in coastal acidification events (Chavez et al., 2017). As mentioned in Sect. 3.2, upwelling-favorable winds along this coast have intensified over recent years, especially in the northern parts of the upwelling regime (García-Reyes et al., 2015; Rykaczewski and Checkley, 2008; Rykaczewski et al., 2015; Sydeman et al., 2014). Intensified upwelling supplies deep water to the shelf that is rich in DIC and nutrients but poor in oxygen. Ocean acidification and hypoxia are thus strongly linked ecosystem stressors because low- oxygen, high- $\mathrm{CO}_{2}$ conditions derive from the microbial respiration of organic matter (Feely et al., 2008, 2016, 2018). In the northern California Current System, $p \mathrm{CO}_{2}, \mathrm{pH}$, and aragonite saturation reach levels known to be harmful to ecologically and economically important species during the summer upwelling season (Barton et al., 2012, 2015; Bednaršek et al., 2014, 2016, 2017; Feely et al., 2008, 2016; Harris et al., 2013; Sutton et al., 2016). In the Gulf of Alaska, aragonite saturation drops to near saturation values during the winter months when deep mixing occurs and surface ocean $p \mathrm{CO}_{2}$ exceeds atmospheric $p \mathrm{CO}_{2}$ (Evans and Mathis, 2013). Along the Pacific coast, $50 \%$ of shelf waters are projected to experience year-long undersaturation by 2050 (Gruber et al., 2012; Hauri et al., 2013; Turi et al., 2016).

Polar regions are naturally prone to low $\mathrm{pH}$ values (Orr et al., 2005; Steinacher et al., 2009) and thus closer to critical acidification thresholds than lower-latitude waters. The low $\mathrm{pH}$ levels result from the naturally high ratio of DIC to alkalinity in polar waters due to their low temperatures, multiple sources of freshwater (e.g., riverine, glacial melt, and sea ice melt), and high respiratory DIC content. In addition to the naturally low $\mathrm{pH}$, the rate of acidification is relatively high in polar waters (Feely et al., 2009; Mathis et al., 2015; Sutton et al., 2016) because retreating sea ice adds meltwater from multiyear ice and increases the surface area of open water, thereby enhancing the uptake of atmospheric $\mathrm{CO}_{2}$ (Cai et al., 2010a; Steiner et al., 2013). The Beaufort Sea upper halocline and deep waters already show aragonite undersaturation, i.e., aragonite saturation states below 1, favoring dissolution (Mathis et al., 2015; Miller et al., 2014). These chemical seawater signatures are propagated via M'Clure Strait and Amundsen Gulf into the Canadian Arctic shelf and beyond (Azetsu-Scott et al., 2010; Turk et al., 2016; YamamotoKawai et al., 2013). Model projections based on the IPCC high- $\mathrm{CO}_{2}$ emissions scenario RCP8.5 suggest the Beaufort Sea surface water will become undersaturated with respect to aragonite around 2025 (Steinacher et al., 2009; Steiner et al., 2014). As these conditions intensify, negative impacts for calcifying marine organisms are expected to become a critical issue reshaping ecosystems and fisheries across the Arctic (Moore and Stabeno, 2015).

In contrast, surface aragonite saturation states typically range from 3.6 to 4.5 and are thus well above the dissolution threshold in the northern Gulf of Mexico (Wang et al., 2013; Wanninkhof et al., 2015). Here excessive nutrient inputs from the Mississippi River result in hypoxia and the eutrophication-induced acidification of near-bottom waters (Cai et al., 2011; Laurent et al., 2017). Similar to the California Current System, low-oxygen and high- $\mathrm{CO}_{2}$ conditions coincide and derive from the microbial respiration of organic matter (Cai et al., 2011; Laurent et al., 2017; Feely et al., 2018). Currently, aragonite saturation states are around 2 in hypoxic bottom waters and thus well above the saturation threshold. Projections suggest that the aragonite saturation states of these near-bottom waters will drop below the satu- 
ration threshold near the end of this century (Laurent et al., 2018).

Along the Atlantic coast, the northern regions (the MidAtlantic Bight and Gulf of Maine) have, on average, lower $\mathrm{pH}$ and lower aragonite saturation states than more southern coastal regions (i.e., the South Atlantic Bight) (Wang et al., 2013; Wanninkhof et al., 2015; Sutton et al., 2016). These properties are primarily explained by a decrease in alkalinity from the SAB toward the GOM. The seasonal undersaturation of aragonite in subsurface water is already occurring in the GOM, which supports a significant shellfish industry (Wang et al., 2017).

\section{Conclusions}

Tremendous progress has been made during the last decade in improving understanding and constraining rates of carbon cycling in coastal waters because of a greatly expanded suite of observations, process studies, and models. However, the quantification of many coastal carbon fluxes remains difficult. One of the challenges is that carbon is constantly exchanged across a multitude of interfaces, i.e., the sea surface and the interfaces between land and coastal ocean, coastal, and open-ocean waters, as well as water and sediment. Furthermore, net exchange fluxes and trends are relatively small signals masked by a large and fluctuating background. At present, most of these fluxes are not quantified well enough to derive well-constrained carbon budgets for North American coastal waters or to project how those fluxes will change in the future due to various drivers.

This synthesis focused primarily on the role of ocean margins in sequestering atmospheric $\mathrm{CO}_{2}$ and coastal ocean acidification. In the coastal ocean, a net removal of carbon from direct interaction with the atmosphere can occur through the export of dissolved or particulate carbon to the deep ocean or through permanent burial in sediments. Neither of these is easily observed or well quantified. The bestobserved flux is gas exchange across the air-sea interface, although extracting the small net flux and its trend from a variable background with large-amplitude seasonal fluctuations is difficult. Ultimately, the uptake of anthropogenic carbon is the relevant quantity for assessing the contribution of ocean margins to the total ocean uptake of anthropogenic carbon; however, the separation of anthropogenic fluxes from the natural background is thus far elusive for coastal waters. The only available estimates are from a global modeling study (Bourgeois et al., 2016).

Estimates of air-sea $\mathrm{CO}_{2}$ fluxes currently provide the best evidence for the contribution of coastal waters to overall carbon uptake by the ocean. Our synthesis of regional studies shows that, overall, the North American coastal waters act as a sink of atmospheric $\mathrm{CO}_{2}$. The limited temporal and spatial footprint of many of these studies and gaps in spatial coverage (e.g., no estimates exist for the Labrador Sea and
Canadian Arctic shelf) prevented us from combining these regional studies into a summary estimate for the North American EEZ. Instead, we compared the regional studies to the global model of Bourgeois et al. (2016) for a fine-grained decomposition of the North American EEZ. The reasonable agreement between the regional studies and estimates from the global model builds some confidence in the model estimate of $160 \mathrm{Tg} \mathrm{C} \mathrm{yr}^{-1}$ of uptake for the North American EEZ

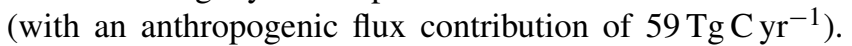
The Labrador Sea, Gulf of Alaska, and Bering Sea are the biggest contributors, making up more than half of the total uptake (and almost half of the anthropogenic uptake) while accounting for less than one-third of the surface area of the EEZ. The Arctic and sub-Arctic, mid-latitude Atlantic, and mid-latitude Pacific account for 104, 62, and $-3.7 \mathrm{Tg} \mathrm{C} \mathrm{yr}^{-1}$, respectively, while making up $51 \%, 25 \%$, and $24 \%$ of the total area, respectively. The comparatively large uptake along the mid-latitude Atlantic simulated in the global model of Bourgeois et al. (2016) is larger than regional estimates (e.g., Signorini et al., 2013), likely because it significantly underestimates the residence times of coastal waters (Rutherford and Fennel, 2018). Nevertheless, we used this flux estimate, assuming an uncertainty of $50 \%$, to construct a first carbon budget for the North American EEZ. The estimated uptake of atmospheric carbon of $160 \pm 80 \mathrm{Tg} \mathrm{C} \mathrm{yr}^{-1}$ combined with an input from land of $106 \pm 30 \mathrm{Tg} \mathrm{Cyr}^{-1}$ (Windham-Myers et al., 2018) minus an estimated burial of $65 \pm 55{\mathrm{Tg} \mathrm{C} \mathrm{yr}^{-1}}^{-1}$ leads to a large net addition of carbon. This term has to be balanced by carbon storage in waters of the EEZ and export to the open ocean. The estimated carbon storage of $50 \pm 25 \mathrm{Tg} \mathrm{C} \mathrm{yr}^{-1}$ from the global model leads to a carbon export of $151 \pm 105 \mathrm{Tg} \mathrm{C} \mathrm{yr}^{-1}$ to the open ocean. The estimated uptake of atmospheric carbon in the North American EEZ amounts to $6.4 \%$ of the global ocean uptake of atmospheric $\mathrm{CO}_{2}$ of $2500 \mathrm{Tg} \mathrm{Cyr}^{-1}$ (). Given that the North American EEZ is about $4 \%$ of the global ocean surface area, its uptake of $\mathrm{CO}_{2}$ is about $50 \%$ more efficient than the global average.

Coastal waters contribute significantly to the carbon budget of North America. According to Birdsey et al. (2018), the coastal carbon sink estimated here is about one-quarter of the net carbon sink on land in North America (606 Tg C yr ${ }^{-1}$ is the net uptake by ecosystems and tidal wetlands minus emissions from harvested wood, inland waters, and estuaries). Coastal waters of North America are also a key component of aquatic carbon fluxes; specifically, much of the large net outgassing of $\mathrm{CO}_{2}$ from inland waters, estimated at $247 \mathrm{Tg} \mathrm{C} \mathrm{yr}^{-1}$ (Butman et al., 2018), is offset by coastal ocean uptake.

Several drivers influence secular trends in coastal carbon fluxes and will continue to do so in the future. These drivers include the direct effect of rising atmospheric $\mathrm{CO}_{2}$ levels and indirect effects due to changes in atmosphere-ocean interactions (e.g., wind forcing and heat fluxes), changes in the hydrological cycle, and anthropogenic perturbations of global nutrient cycling (particularly, the nitrogen cycle). The direct 
effect of rising atmospheric $\mathrm{CO}_{2}$ levels alone will likely amplify coastal $\mathrm{CO}_{2}$ uptake and carbon export, at least until the ocean's buffering capacity is significantly reduced, but the extent of this increase will depend on the rate of the atmospheric $\mathrm{CO}_{2}$ rise, the residence time of shelf waters, and the carbon content of open-ocean source waters supplied to coastal regions. Indeed, there is observational evidence for a strengthening of coastal ocean carbon export from increasing trends in the air-sea $p \mathrm{CO}_{2}$ gradient for the Labrador Sea, Vancouver shelf, and South Atlantic Bight (Laruelle et al., 2018). Several indirect effects such the enhanced subduction of upwelled water along the Pacific margin (Evans et al., 2015a), increased stratification on the shelf (Laurent et al., 2018), and decreased $\mathrm{CO}_{2}$ solubility due to warming (Cahill et al., 2016) will partly counteract a strengthening of the coastal $\mathrm{CO}_{2}$ uptake. On Arctic shelves, significant releases of the potent greenhouse gas $\mathrm{CH}_{4}$ will result from melting permafrost (Parmentier et al., 2013).

A major concern is coastal acidification, which can affect the growth, metabolism, and life cycles of many marine organisms, specifically calcifiers, and can trigger cascading ecosystem-scale effects. Most vulnerable are those organisms that precipitate aragonite, one of the more soluble forms of biogenic $\mathrm{CaCO}_{3}$ in the ocean. The Arctic Ocean is naturally closer to critical acidification thresholds with subsurface waters in the Beaufort Sea already routinely below aragonite saturation (favoring dissolution) (Mathis et al., 2015; Miller et al., 2014). Model projections show undersaturation in surface waters in the Beaufort Sea by 2025 (Steiner et al., 2014). Along the Pacific coast, atmospheric $\mathrm{CO}_{2}$ uptake in combination with intensified upwelling that brings low-pH, low-oxygen water onto the shelves leads to aragonite levels below the saturation threshold in large portions of the subsurface waters (Feely et al., 2016, 2018; Chavez et al., 2017). Here half of the shelf is projected to be undersaturated by 2050 (Gruber et al., 2012; Hauri et al., 2013; Turi et al., 2016). In the northern Gulf of Mexico, aragonite saturation states are currently well above the dissolution threshold despite the eutrophication-induced acidification occurring in bottom waters due to Mississippi River inputs of nutrients and freshwater (Cai et al., 2011; Laurent et al., 2017). Here undersaturation is projected to occur by 2100 (Laurent et al., 2018).

Given the importance of coastal margins, both in contributing to carbon budgets and in the societal benefits they provide, further efforts to improve assessments of the carbon cycle in these regions are paramount. Critical needs are maintaining and expanding existing coastal observing programs, continued national and international coordination, and the integration of observations, modeling capabilities, and stakeholder needs.

Data availability. All data sets used in this synthesis are publicly available at the sources indicated.
Supplement. The supplement related to this article is available online at: https://doi.org/10.5194/bg-16-1281-2019-supplement.

Author contributions. KF wrote the paper with contributions from all co-authors.

Competing interests. The authors declare that they have no conflict of interest.

Acknowledgements. This paper builds on synthesis activities carried out for the second State of the Carbon Cycle Report (SOCCR2). We would like to thank Gyami Shrestha, Nancy Cavallero, Melanie Mayes, Holly Haun, Marjy Friedrichs, Laura Lorenzoni, and Erica Ombres for the guidance and input. We are grateful to Nicolas Gruber and Christophe Rabouille for their constructive and helpful reviews of the paper. It is a contribution to the Marine Biodiversity Observation Network (MBON), the Integrated Marine Biosphere Research (IMBeR) project, the International Ocean Carbon Coordination Project (IOCCP), and the Cooperative Institute of the University of Miami and the National Oceanic and Atmospheric Administration (CIMAS) under cooperative agreement NA10OAR4320143. Katja Fennel was funded by the NSERC Discovery program. Steven Lohrenz was funded by NASA grant NNX14AO73G. Ray Najjar was funded by NASA grant NNX14AM37G. Frank Muller-Karger was funded through NASA grant NNX14AP62A. This is Pacific Marine Environmental Laboratory contribution number 4837 and Lamont-Doherty Earth Observatory contribution number 8284. Simone Alin and Richard A. Feely also thank Libby Jewett and Dwight Gledhill of the NOAA Ocean Acidification Program for their support.

Review statement. This paper was edited by Jack Middelburg and reviewed by Nicolas Gruber and Christophe Rabouille.

\section{References}

Aksnesa, D. L. and Ohman, M. D.: Multi-decadal shoaling of the euphotic zone in the southern sector of the California Current System, Limnol. Oceanogr., 54, 1272-1281, 2009.

Azetsu-Scott, K., Clarke, A., Falkner, K., Hamilton, J., Jones, E. P., Lee, C., Petrie, B., Prinsenberg, S., Starr, M., and Yeats, P.: Calcium carbonate saturation states in the waters of the Canadian Arctic Archipelago and the Labrador Sea, J. Geophys. Res.Ocean., 115, C11021, https://doi.org/10.1029/2009JC005917, 2010.

Bakker, D. C. E., Pfeil, B., Smith, K., Hankin, S., Olsen, A., Alin, S. R., Cosca, C., Harasawa, S., Kozyr, A., Nojiri, Y., O’Brien, K. M., Schuster, U., Telszewski, M., Tilbrook, B., Wada, C., Akl, J., Barbero, L., Bates, N. R., Boutin, J., Bozec, Y., Cai, W.-J., Castle, R. D., Chavez, F. P., Chen, L., Chierici, M., Currie, K., de Baar, H. J. W., Evans, W., Feely, R. A., Fransson, A., Gao, Z., Hales, B., Hardman-Mountford, N. J., Hoppema, M., Huang, W.-J., Hunt, C. W., Huss, B., Ichikawa, T., Johan- 
nessen, T., Jones, E. M., Jones, S. D., Jutterström, S., Kitidis, V., Körtzinger, A., Landschützer, P., Lauvset, S. K., Lefèvre, N., Manke, A. B., Mathis, J. T., Merlivat, L., Metzl, N., Murata, A., Newberger, T., Omar, A. M., Ono, T., Park, G.-H., Paterson, K., Pierrot, D., Ríos, A. F., Sabine, C. L., Saito, S., Salisbury, J., Sarma, V. V. S. S., Schlitzer, R., Sieger, R., Skjelvan, I., Steinhoff, T., Sullivan, K. F., Sun, H., Sutton, A. J., Suzuki, T., Sweeney, C., Takahashi, T., Tjiputra, J., Tsurushima, N., van Heuven, S. M. A. C., Vandemark, D., Vlahos, P., Wallace, D. W. R., Wanninkhof, R., and Watson, A. J.: An update to the Surface Ocean $\mathrm{CO}_{2}$ Atlas (SOCAT version 2), Earth Syst. Sci. Data, 6, 69-90, https://doi.org/10.5194/essd-6-69-2014, 2014.

Bakun, A.: Global climate change and intensification of coastal ocean upwelling, Science, 247, 198-201, 1990.

Barrón, C. and Duarte, C. M.: Dissolved organic carbon pools and export from the coastal ocean, Global Biogeochem. Cy., 29, 1725-1738, 2015.

Barth, J. A., Cowles, T. J., Kosro, P. M., Shearman, R. K., Huyer, A., and Smith, R. L.: Injection of carbon from the shelf to offshore beneath the euphotic zone in the California Current, J. Geophys. Res.-Ocean., 107, C63057, https://doi.org/10.1029/2001jc000956, 2002.

Barton, A., Hales, B., Waldbusser, G. G., Langdon, C., and Feely, R. A.: The Pacific oyster, Crassostrea gigas, shows negative correlation to naturally elevated carbon dioxide levels: Implications for near-term ocean acidification effects, Limnol. Oceanogr., 57, 698-710, 2012.

Barton, A., Waldbusser, G. G., Feely, R. A., Weisberg, S. B., Newton, J. A., Hales, B., Cudd, S., Eudeline, B., Langdon, C. J., Jefferds, I., King, T., Suhrbier, A., and McLauglin, K.: Impacts of coastal acidification on the Pacific Northwest shellfish industry and adaptation strategies implemented in response, Oceanography, 28, 146-159, 2015.

Bates, N. R. and Mathis, J. T.: The Arctic Ocean marine carbon cycle: evaluation of air-sea $\mathrm{CO}_{2}$ exchanges, ocean acidification impacts and potential feedbacks, Biogeosciences, 6, 2433-2459, https://doi.org/10.5194/bg-6-2433-2009, 2009.

Bates, N. R.: Air-sea $\mathrm{CO}_{2}$ fluxes and the continental shelf pump of carbon in the Chukchi Sea adjacent to the Arctic Ocean, J. Geophys. Res.-Ocean., 111, C10013, https://doi.org/10.1029/2005jc003083, 2006.

Bednaršek, N., Feely, R., Reum, J., Peterson, B., Menkel, J., Alin, S., and Hales, B.: Limacina helicina shell dissolution as an indicator of declining habitat suitability owing to ocean acidification in the California Current Ecosystem, P. R. Soc. B, 281, 20140123, https://doi.org/10.1098/rspb.2014.0123, 2014.

Bednaršek, N., Harvey, C. J., Kaplan, I. C., Feely, R. A., and Možina, J.: Pteropods on the edge: Cumulative effects of ocean acidification, warming, and deoxygenation, Prog. Oceanogr., 145, 1-24, 2016.

Bednaršek, N., Feely, R., Tolimieri, N., Hermann, A., Siedlecki, S., Waldbusser, G., McElhany, P., Alin, S., Klinger, T., MooreMaley, B., and Pörtner, H. O.: Exposure history determines pteropod vulnerability to ocean acidification along the US West Coast, Sci. Rep., 7, 4526, https://doi.org/10.1038/s41598-017-03934-z, 2017.

Benway, H. M. and Coble, P. G.: Report of the U.S. Gulf of Mexico Carbon Cycle Synthesis Workshop, 27-28 March 2013, Ocean
Carbon and Biogeochemistry Program and North American Carbon Program, 2014.

Benway, H. M., Alin, S. R., Boyer, E., Cai, W.-J., Coble, P. G., Cross, J. N., Friedrichs, M. A., Goni, M., Griffith, P., Herrmann, M., Lohrenz, S., Mathis, J., McKinley, G., Najjar, R., Pilskaln, C., Siedlecki, S., and Smith, R. L.: A science plan for carbon cycle research in North American coastal waters. Report of the Coastal CARbon Synthesis (CCARS) community workshop, 1921 August 2014, 2016.

Birdsey, R., Mayes, M., Romero-Lankao, P., Najjar, R., Reed, S., Cavallaro, N., Shrestha, G., Hayes, D., Lorenzoni, L., Marsh, A., Tedesco, K., Wirth, T., and Zhu, Z.: Executive Summary, in: Second State of the Carbon Cycle Report (SOCCR2): A Sustained Assessment Report, edited by: Cavallaro, N., Shrestha, G., Birdsey, R., Mayes, M. A., Najjar, R. G., Reed, S. C., RomeroLankao, P., and Zhu, Z., US Global Change Research Program, Washington, DC, USA, 21-40, 2018.

Bograd, S. J., Buil, M. P., Di Lorenzo, E., Castro, C. G., Schroeder, I. D., Goericke, R., Anderson, C. R., Benitez-Nelson, C., and Whitney, F. A.: Changes in source waters to the Southern California Bight, Deep-Sea Res. Pt. II, 112, 42-52, 2015.

Bourgeois, T., Orr, J. C., Resplandy, L., Terhaar, J., Ethé, C., Gehlen, M., and Bopp, L.: Coastal-ocean uptake of anthropogenic carbon, Biogeosciences, 13, 4167-4185, https://doi.org/10.5194/bg-13-4167-2016, 2016.

Brothers, L., Van Dover, C., German, C. R., Kaiser, C. L., Yoerger, D., Ruppel, C., Lobecker, E., Skarke, A., and Wagner, J.: Evidence for extensive methane venting on the southeastern US Atlantic margin, Geology, 41, 807-810, 2013.

Butman, D., Striegl, R., Stackpoole, S., del Giorgio, P., Prairie, Y., Pilcher, D., Raymond, P., Paz Pellat, F., and Alcocer, J.: Chapter 14: Inland waters, in: Second State of the Carbon Cycle Report (SOCCR2): A Sustained Assessment Report, edited by: Cavallaro, N., Shrestha, G., Birdsey, R., Mayes, M. A., Najjar, R. G., Reed, S. C., Romero-Lankao, P., and Zhu, Z., U.S. Global Change Research Program, Washington, DC, USA, 568595, 2018.

Butterworth, B. J. and Miller, S. D.: Air-sea exchange of carbon dioxide in the Southern Ocean and Antarctic marginal ice zone, Geophys. Res. Lett., 43, 7223-7230, 2016.

Cahill, B., Wilkin, J., Fennel, K., Vandemark, D., and Friedrichs, M. A.: Interannual and seasonal variabilities in air-sea $\mathrm{CO}_{2}$ fluxes along the US eastern continental shelf and their sensitivity to increasing air temperatures and variable winds, J. Geophys Res.-Biogeo., 121, 295-311, 2016.

Cai, W.-J.: Estuarine and coastal ocean carbon paradox: $\mathrm{CO}_{2}$ sinks or sites of terrestrial carbon incineration?, Ann. Rev. Mar. Sci., 3, 123-145, 2011

Cai, W.-J. and Wang, Y.: The chemistry, fluxes, and sources of carbon dioxide in the estuarine waters of the Satilla and Altamaha Rivers, Georgia, Limnol. Oceanogr., 43, 657-668, 1998.

Cai, W.-J., Wang, Z. A., and Wang, Y.: The role of marsh-dominated heterotrophic continental margins in transport of $\mathrm{CO}_{2}$ between the atmosphere, the land-sea interface and the ocean, Geophys. Res. Lett., 30, 1849, https://doi.org/10.1029/2003g1017633, 2003.

Cai, W.-J., Chen, L., Chen, B., Gao, Z., Lee, S. H., Chen, J., Pierrot, D., Sullivan, K., Wang, Y., Hu, X., Huang, W. J., Zhang, Y., Xu, S., Murata, A., Grebmeier, J. M., Jones, E. P., and Zhang, H.: 
Decrease in the $\mathrm{CO}_{2}$ uptake capacity in an ice-free Arctic Ocean basin, Science, 329, 556-559, 2010a.

Cai, W.-J., Hu, X., Huang, W.-J., Jiang, L.-Q., Wang, Y., Peng, T.H., and Zhang, X.: Alkalinity distribution in the western North Atlantic Ocean margins, J. Geophys. Res.-Ocean., 115, C08014, https://doi.org/10.1029/2009jc005482, 2010b.

Cai, W.-J., Hu, X., Huang, W.-J., Murrell, M. C., Lehrter, J. C., Lohrenz, S. E., Chou, W.-C., Zhai, W., Hollibaugh, J. T., Wang, Y., Zhao, P., Guo, X., Gundersen, K., Dai, M., and Gong, G.-C.: Acidification of subsurface coastal waters enhanced by eutrophication, Nat. Geosci., 4, 766-770, 2011.

Cai, W.-J., Bates, N. R., Guo, L., Anderson, L. G., Mathis, J. T., Wanninkhof, R., Hansell, D. A., Chen, L., and Semiletov, I. P.: Carbon fluxes across boundaries in the Pacific Arctic region in a changing environment, in: The Pacific Arctic Region, Springer, 199-222, 2014.

Caldeira, K. and Wicke, M. E.: Oceanography: Anthropogenic carbon and Ocean $\mathrm{pH}$, Nature, 425, p. 365, https://doi.org/10.1038/425365a, 2003.

Canadell, J. G., Le Quéré, C., Raupach, M. R., Field, C. B., Buitenhuis, E. T., Ciais, P., Conway, T. J., Gillett, N. P., Houghton, R., and Marland, G.: Contributions to accelerating atmospheric $\mathrm{CO}_{2}$ growth from economic activity, carbon intensity, and efficiency of natural sinks, P. Natl. Acad. Sci. USA, 104, 18866-18870, 2007

Canals, M., Puig, P., de Madron, X. D., Heussner, S., Palanques, A., and Fabres, J.: Flushing submarine canyons, Nature, 444, 354357, 2006.

Carmack, E., Barber, D., Christensen, J., Macdonald, R., Rudels, B., and Sakshaug, E.: Climate variability and physical forcing of the food webs and the carbon budget on Panarctic shelves, Prog. Oceanogr., 71, 145-181, 2006.

Carmack, E., Winsor, P., and Williams, W.: The contiguous Panarctic riverine coastal domain: A unifying concept, Prog. Oceanogr., 139, 13-23, 2015.

Chapa-Balcorta, C., Hernandez-Ayon, J. M., Durazo, R., Beier, E., Alin, S. R., and López-Pérez, A.: Influence of post-Tehuano oceanographic processes in the dynamics of the $\mathrm{CO}_{2}$ system in the Gulf of Tehuantepec, Mexico, J. Geophys. Res.-Ocean., 120, 7752-7770, 2015.

Chavez, F., Takahashi, P. T., Cai, W. J., Friederich, G. E., Hales, B., Wanninkhof, R., and Feely, R. A.: Coastal oceans, in: First State of the Carbon Cycle Report (SOCCR): The North American Carbon Budget and Implications for the Global Carbon Cycle. A Report by the U.S. Climate Change Science Program and the Subcommittee on Global Change Research, edited by: King, A., Dilling, W. L., Zimmerman, G. P., Fairman, D. M., Houghton, R. A., Marland, G., Rose, A. Z., and Wilbanks, T., chap. 15, National Oceanic and Atmospheric Administration, National Climatic Data Center, Asheville, 157-166, 2007.

Chavez, F. P., Messié, M., and Pennington, J. T.: Marine primary production in relation to climate variability and change, Ann. Rev. Mar. Sci., 3, 227-260, 2011.

Chavez, F. P., Pennington, J. T., Michisaki, R. P., Blum, M., Chavez, G. M., Friederich, J., Jones, B., Herlien, R., Kieft, B., Hobson, B., Ren, A. S., Ryan, J., Sevadjian, J. C., Wahl, C., Walz, K. R., Yamahara, K., Friederich, G. E., and Messié, M.: Climate variability and change: Response of a coastal ocean ecosystem, Oceanography, 30, 128-145, 2017.
Chelton, D. B., Freilich, M. H., and Esbensen, S. K.: Satellite observations of the wind jets off the Pacific coast of Central America. Part I: Case studies and statistical characteristics, Mon. Weather Rev., 128, 1993-2018, 2000a.

Chelton, D. B., Freilich, M. H., and Esbensen, S. K.: Satellite observations of the wind jets off the Pacific coast of Central America. Part II: Regional relationships and dynamical considerations, Mon. Weather Rev., 128, 2019-2043, 2000b.

Chen, C. T. A.: Exchange of carbon in the coastal seas, in: The global carbon cycle: integrating humans, climate, and the natural world, edited by: Field, C. B. and Raupach, M. R., vol. 62, SCOPE, Washington, DC, 341-351, 2004.

Coronado-Álvarez, L. d. L. A., Álvarez-Borrego, S., Lara-Lara, J. R., Solana-Arellano, E., Hernández-Ayón, J. M., and Zirino, A.: Temporal variations of water $p \mathrm{CO}_{2}$ and the air-water $\mathrm{CO}_{2}$ flux at a coastal location in the southern California Current System: diurnal to interannual scales, Cienc. Mar., 43, 137-156, 2017.

Crabeck, O., Delille, B., Thomas, D., Geilfus, N.-X., Rysgaard, S., and Tison, J.-L.: $\mathrm{CO}_{2}$ and $\mathrm{CH}_{4}$ in sea ice from a subarctic fjord under influence of riverine input, Biogeosciences, 11, 6525-6538, https://doi.org/10.5194/bg-11-6525-2014, 2014.

Crawford, W. R. and Peña, M. A.: Decadal trends in oxygen concentration in subsurface waters of the Northeast Pacific Ocean, Atmos. Ocean, 54, 171-192, 2016.

Cross, J., Mathis, J., Monacci, N., Musielewicz, S., Maenner, S., and Osborne, J.: High-resolution Ocean and Atmosphere $p \mathrm{CO}_{2}$ Time-series Measurements from Mooring M2_164W_57N, https://doi.org/10.3334/CDIAC/OTG.TSM_M2_164W_57N, 2014a.

Cross, J. N., Mathis, J. T., Frey, K. E., Cosca, C. E., Danielson, S. L., Bates, N. R., Feely, R. A., Takahashi, T., and Evans, W.: Annual sea-air $\mathrm{CO}_{2}$ fluxes in the Bering Sea: Insights from new autumn and winter observations of a seasonally ice-covered continental shelf, J. Geophys. Res.-Ocean., 119, 6693-6708, 2014b.

DeGrandpre, M., Olbu, G., Beatty, C., and Hammar, T.: Air-sea $\mathrm{CO}_{2}$ fluxes on the US Middle Atlantic Bight, Deep-Sea Res. Pt. II, 49, 4355-4367, 2002.

Déry, S. J., Stieglitz, M., McKenna, E. C., and Wood, E. F.: Characteristics and trends of river discharge into Hudson, James, and Ungava Bays, 1964-2000, J. Clim., 18, 2540-2557, 2005.

Dieckmann, G. S., Nehrke, G., Papadimitriou, S., Göttlicher, J., Steininger, R., Kennedy, H., Wolf-Gladrow, D., and Thomas, D. N.: Calcium carbonate as ikaite crystals in Antarctic sea ice, Geophys. Res. Lett., 35, L08501, https://doi.org/10.1029/2008g1033540, 2008.

Dunne, J. P., Sarmiento, J. L., and Gnanadesikan, A.: A synthesis of global particle export from the surface ocean and cycling through the ocean interior and on the seafloor, Global Biogeochem. Cy., 21, GB4006, https://doi.org/10.1029/2006gb002907, 2007.

Else, B., Papakyriakou, T., Asplin, M., Barber, D., Galley, R., Miller, L., and Mucci, A.: Annual cycle of air-sea $\mathrm{CO}_{2}$ exchange in an Arctic polynya region, Global Biogeochem. Cy., 27, 388398, 2013.

Else, B. G., Papakyriakou, T. N., Granskog, M. A., and Yackel, J. J.: Observations of sea surface $f \mathrm{CO}_{2}$ distributions and estimated air-sea $\mathrm{CO}_{2}$ fluxes in the Hudson Bay region (Canada) during the open water season, J. Geophys. Res.-Ocean., 113, C08026, https://doi.org/10.1029/2007jc004389, 2008. 
Evans, W. and Mathis, J. T.: The Gulf of Alaska coastal ocean as an atmospheric $\mathrm{CO}_{2}$ sink, Cont. Shelf Res., 65, 52-63, 2013.

Evans, W., Hales, B., and Strutton, P. G.: Seasonal cycle of surface ocean $p \mathrm{CO}_{2}$ on the Oregon shelf, J. Geophys. Res.-Ocean., 116, C05012, https://doi.org/10.1029/2010jc006625, 2011.

Evans, W., Hales, B., Strutton, P. G., and Ianson, D.: Sea-air $\mathrm{CO}_{2}$ fluxes in the western Canadian coastal ocean, Prog. Oceanogr., 101, 78-91, 2012.

Evans, W., Hales, B., Strutton, P. G., Shearman, R. K., and Barth, J. A.: Failure to bloom: Intense upwelling results in negligible phytoplankton response and prolonged $\mathrm{CO}_{2}$ outgassing over the Oregon shelf, J. Geophys. Res.-Ocean., 120, 1446-1461, 2015 a.

Evans, W., Mathis, J. T., Cross, J. N., Bates, N. R., Frey, K. E., Else, B. G., Papkyriakou, T. N., DeGrandpre, M. D., Islam, F., Cai, W.-J., Chen, B., Yamamoto-Kawai, M., Carmack, E., Williams, W. J., and Takahashi, T.: Sea-air $\mathrm{CO}_{2}$ exchange in the western Arctic coastal ocean, Global Biogeochem. Cy., 29, 1190-1209, $2015 b$.

Fabry, V. J., Seibel, B. A., Feely, R. A., and Orr, J. C.: Impacts of ocean acidification on marine fauna and ecosystem processes, ICES J. Mar. Sci., 65, 414-432, 2008.

Feely, R. A., Sabine, C. L., Lee, K., Berelson, W., Kleypas, J., Fabry, V. J., and Millero, F. J.: Impact of anthropogenic $\mathrm{CO}_{2}$ on the $\mathrm{CaCO}_{3}$ system in the oceans, Science, 305, 362-366, 2004.

Feely, R. A., Sabine, C. L., Hernandez-Ayon, J. M., Ianson, D., and Hales, B.: Evidence for upwelling of corrosive "acidified" water onto the continental shelf, Science, 320, 1490-1492, 2008.

Feely, R. A., Doney, S. C., and Cooley, S. R.: Ocean acidification: Present conditions and future changes in a high- $\mathrm{CO}_{2}$ world, Oceanography, 22, 36-47, 2009.

Feely, R. A., Alin, S. R., Carter, B., Bednaršek, N., Hales, B., Chan, F., Hill, T. M., Gaylord, B., Sanford, E., Byrne, R. H., Sabine, C. L., Greeley, D., and Juranek, L.: Chemical and biological impacts of ocean acidification along the west coast of North America, Estuarine, Coast. Shelf Sci., 183, 260-270, 2016.

Feely, R. A., Okazaki, R. R., Cai, W.-J., Bednaršek, N., Alin, S. R., Byrne, R. H., and Fassbender, A.: The combined effects of acidification and hypoxia on $\mathrm{pH}$ and aragonite saturation in the coastal waters of the California current ecosystem and the northern Gulf of Mexico, Cont. Shelf Res., 152, 50-60, 2018.

Fennel, K.: The role of continental shelves in nitrogen and carbon cycling: Northwestern North Atlantic case study, Ocean Sci., 6, 539-548, https://doi.org/10.5194/os-6-539-2010, 2010.

Fennel, K. and Wilkin, J.: Quantifying biological carbon export for the northwest North Atlantic continental shelves, Geophys. Res. Lett., 36, L18605, https://doi.org/10.1029/2009g1039818, 2009.

Fennel, K., Wilkin, J., Previdi, M., and Najjar, R.: Denitrification effects on air-sea $\mathrm{CO}_{2}$ flux in the coastal ocean: Simulations for the northwest North Atlantic, Geophys. Res. Lett., 35, L24608, https://doi.org/10.1029/2008g1036147, 2008.

Fiechter, J., Curchitser, E. N., Edwards, C. A., Chai, F., Goebel, N. L., and Chavez, F. P.: Air-sea $\mathrm{CO}_{2}$ fluxes in the California Current: Impacts of model resolution and coastal topography, Global Biogeochem. Cy., 28, 371-385, 2014.

Franco, A. C., Hernández-Ayón, J. M., Beier, E., Garçon, V., Maske, H., Paulmier, A., Färber-Lorda, J., Castro, R., and Sosa-Ávalos, R.: Air-sea $\mathrm{CO}_{2}$ fluxes above the stratified oxygen minimum zone in the coastal region off Mexico, J. Geophys. Res.-Ocean., 119, 2923-2937, 2014.
Friederich, G., Walz, P., Burczynski, M., and Chavez, F.: Inorganic carbon in the central California upwelling system during the 1997-1999 El Niño-La Niña event, Prog. Oceanogr., 54, 185203, 2002.

Frischknecht, M., Münnich, M., and Gruber, N.: Origin, Transformation, and Fate: The Three-Dimensional Biological Pump in the California Current System, J. Geophys. Res.-Ocean., 123, 7939-7962, 2018.

Gao, Z., Chen, L., Sun, H., Chen, B., and Cai, W.-J.: Distributions and air-sea fluxes of carbon dioxide in the Western Arctic Ocean, Deep-Sea Res. Pt. II, 81, 46-52, 2012.

García-Reyes, M., Sydeman, W. J., Schoeman, D. S., Rykaczewski, R. R., Black, B. A., Smit, A. J., and Bograd, S. J.: Under pressure: Climate change, upwelling, and eastern boundary upwelling ecosystems, Front. Mar. Sci., 2, 109, https://doi.org/10.3389/fmars.2015.00109, 2015.

Gattuso, J.-P. and Hansson, L.: Ocean acidification, Oxford Univ. Press, Oxford, 2011.

Gattuso, J.-P., Frankignoulle, M., and Wollast, R.: Carbon and carbonate metabolism in coastal aquatic ecosystems, Ann. Rev. Ecol. Syst., 29, 405-434, 1998.

Gaxiola-Castro, G. and Muller-Karger, F.: Seasonal phytoplankton pigment variability in the Eastern Tropical Pacific Ocean as determined by CZCS imagery, Remote Sensing of the Pacific Ocean by Satellite, 71-227, 1998.

Gruber, N., Hauri, C., Lachkar, Z., Loher, D., Frölicher, T. L., and Plattner, G.-K.: Rapid progression of ocean acidification in the California Current System, Science, 337, 220-223, 2012.

Hales, B., Takahashi, T., and Bandstra, L.: Atmospheric $\mathrm{CO}_{2}$ uptake by a coastal upwelling system, Global Biogeochem. Cy., 19, GB1009, https://doi.org/10.1029/2004gb002295, 2005.

Hales, B., Karp-Boss, L., Perlin, A., and Wheeler, P. A.: Oxygen production and carbon sequestration in an upwelling coastal margin, Global Biogeochem. Cy., 20, GB3001, https://doi.org/10.1029/2005gb002517, 2006.

Hales, B., Cai, W.-J., Mitchell, B. G., Sabine, C. L., and Schofield, O.: North American continental margins: A synthesis and planning workshop, Report of the North American continental margins working group for the US carbon cycle scientific steering group and interagency working group, US Carbon Cycle Science Program, Washington, DC, 2008.

Hales, B., Strutton, P. G., Saraceno, M., Letelier, R., Takahashi, T., Feely, R., Sabine, C., and Chavez, F.: Satellite-based prediction of $p \mathrm{CO}_{2}$ in coastal waters of the eastern North Pacific, Prog. Oceanogr., 103, 1-15, 2012.

Harris, K. E., DeGrandpre, M. D., and Hales, B.: Aragonite saturation state dynamics in a coastal upwelling zone, Geophys. Res. Lett., 40, 2720-2725, 2013.

Hauri, C., Winsor, P., Juranek, L. W., McDonnell, A. M., Takahashi, T., and Mathis, J. T.: Wind-driven mixing causes a reduction in the strength of the continental shelf carbon pump in the Chukchi Sea, Geophys. Res. Lett., 40, 5932-5936, 2013.

Hautala, S. L., Solomon, E. A., Johnson, H. P., Harris, R. N., and Miller, U. K.: Dissociation of Cascadia margin gas hydrates in response to contemporary ocean warming, Geophys. Res. Lett., 41, 8486-8494, 2014.

Herrmann, M., Najjar, R. G., Kemp, W. M., Alexander, R. B., Boyer, E. W., Cai, W.-J., Griffith, P. C., Kroeger, K. D., McCallister, S. L., and Smith, R. A.: Net ecosystem production and 
organic carbon balance of US East Coast estuaries: A synthesis approach, Global Biogeochem. Cy., 29, 96-111, 2015.

Hickey, B. M.: Coastal oceanography of western North America from the tip of Baja California to Vancouver Island, in: The Global Coastal Ocean: Regional Studies and Syntheses, edited by: Robinson, A. R. and Brink, K. H., vol. 11, New York, Wiley \& Sons, 345-393, 1998.

Ho, D. T., Wanninkhof, R., Schlosser, P., Ullman, D. S., Hebert, D., and Sullivan, K. F.: Toward a universal relationship between wind speed and gas exchange: Gas transfer velocities measured with ${ }^{3} \mathrm{He} / \mathrm{SF} 6$ during the Southern Ocean Gas Exchange Experiment, J. Geophys. Res.-Ocean., 116, C00F04, https://doi.org/10.1029/2010jc006854, 2011.

Ho, D. T., Ferrón, S., Engel, V. C., Anderson, W. T., Swart, P. K., Price, R. M., and Barbero, L.: Dissolved carbon biogeochemistry and export in mangrove-dominated rivers of the Florida Everglades, Biogeosciences, 14, 2543-2559, https://doi.org/10.5194/bg-14-2543-2017, 2017.

Huang, W.-J., Cai, W.-J., Wang, Y., Lohrenz, S. E., and Murrell, M. C.: The carbon dioxide system on the Mississippi Riverdominated continental shelf in the northern Gulf of Mexico: 1. Distribution and air-sea $\mathrm{CO}_{2}$ flux, J. Geophys. Res.-Ocean., 120, 1429-1445, 2015.

Huyer, A.: Coastal upwelling in the California Current system, Prog. Oceanogr., 12, 259-284, 1983.

Ianson, D. and Allen, S. E.: A two-dimensional nitrogen and carbon flux model in a coastal upwelling region, Global Biogeochem. Cy., 16, 1011, https://doi.org/10.1029/2001gb001451, 2002.

IPCC: Workshop Report of the Intergovernmental Panel on Climate Change Workshop on Impacts of Ocean Acidification on Marine Biology and Ecosystems, in: IPCC Working Group II Technical Support Unit, edited by: Field, C. B., Barros, V., Stocker, T. F., Qin, D., Mach, K. J., Plattner, G.-K., Mastrandrea, M. D., Tignor, M., and Eb, K. L., Carnegie Institution, Stanford, p. 164, 2011.

Ivanov, V., Shapiro, G., Huthnance, J., Aleynik, D., and Golovin, P.: Cascades of dense water around the world ocean, Prog. Oceanogr., 60, 47-98, 2004.

Izett, J. G. and Fennel, K.: Estimating the Cross-Shelf Export of Riverine Materials: Part 1. General Relationships From an Idealized Numerical Model, Global Biogeochem. Cy., 32, 160-175, 2018a.

Izett, J. G. and Fennel, K.: Estimating the Cross-Shelf Export of Riverine Materials: Part 2. Estimates of Global Freshwater and Nutrient Export, Global Biogeochem. Cy., 32, 176-186, 2018 b.

Jacox, M. G., Bograd, S. J., Hazen, E. L., and Fiechter, J.: Sensitivity of the California Current nutrient supply to wind, heat, and remote ocean forcing, Geophys. Res. Lett., 42, 5950-5957, 2015.

Jiang, L.-Q., Cai, W.-J., Wanninkhof, R., Wang, Y., and Lüger, H.: Air-sea $\mathrm{CO}_{2}$ fluxes on the US South Atlantic Bight: Spatial and seasonal variability, J. Geophys. Res.-Ocean., 113, C07019, https://doi.org/10.1029/2007jc004366, 2008.

Jiang, L.-Q., Cai, W.-J., Wang, Y., and Bauer, J. E.: Influence of terrestrial inputs on continental shelf carbon dioxide, Biogeosciences, 10, 839-849, https://doi.org/10.5194/bg-10-839-2013, 2013.

Johnson, H. P., Miller, U. K., Salmi, M. S., and Solomon, E. A.: Analysis of bubble plume distributions to evaluate methane hydrate decomposition on the continental slope, Geochem. Geophy. Geosy., 16, 3825-3839, 2015.
Kahru, M., Lee, Z., Kudela, R. M., Manzano-Sarabia, M., and Mitchell, B. G.: Multi-satellite time series of inherent optical properties in the California Current, Deep-Sea Res. Pt. II, 112, 91-106, 2015.

King, A., Dilling, W. L., Zimmerman, G. P., Fairman, D. M., Houghton, R. A., Marland, G., Rose, A. Z., and Wilbanks, T. J.: First State of the Carbon Cycle Report (SOCCR): e North American Carbon Budget and Implications for the Global Carbon Cycle. A Report by the US Climate Change Science Program and the Subcommitee on Global Change Research, National Oceanic and Atmospheric Administration, National Climatic Data Center, Asheville, NC, USA, 157-166, 2007.

Kuzyk, Z. Z. A., Macdonald, R. W., Johannessen, S. C., Gobeil, C., and Stern, G. A.: Towards a sediment and organic carbon budget for Hudson Bay, Mar. Geol., 264, 190-208, 2009.

Laruelle, G. G., Dürr, H. H., Lauerwald, R., Hartmann, J., Slomp, C. P., Goossens, N., and Regnier, P. A. G.: Global multi-scale segmentation of continental and coastal waters from the watersheds to the continental margins, Hydrol. Earth Syst. Sci., 17, 2029-2051, https://doi.org/10.5194/hess-17-2029-2013, 2013.

Laruelle, G. G., Lauerwald, R., Pfeil, B., and Regnier, P.: Regionalized global budget of the $\mathrm{CO}_{2}$ exchange at the air-water interface in continental shelf seas, Global Biogeochem. Cy., 28, 1199-1214, 2014.

Laruelle, G. G., Cai, W.-J., Hu, X., Gruber, N., Mackenzie, F. T., and Regnier, P.: Continental shelves as a variable but increasing global sink for atmospheric carbon dioxide, Nat. Commun., 9, 454, https://doi.org/10.1038/s41467-017-02738-z, 2018.

Laurent, A., Fennel, K., Cai, W.-J., Huang, W.-J., Barbero, L., and Wanninkhof, R.: Eutrophication-induced acidification of coastal waters in the northern Gulf of Mexico: Insights into origin and processes from a coupled physical-biogeochemical model, Geophys. Res. Lett., 44, 946-956, 2017.

Laurent, A., Fennel, K., Ko, D. S., and Lehrter, J.: Climate change projected to exacerbate impacts of coastal eutrophication in the northern Gulf of Mexico, J. Geophys. Res.-Ocean., 123, 34083426, 2018.

Le Quéré, C., Moriarty, R., Andrew, R. M., Canadell, J. G., Sitch, S., Korsbakken, J. I., Friedlingstein, P., Peters, G. P., Andres, R. J., Boden, T. A., Houghton, R. A., House, J. I., Keeling, R. F., Tans, P., Arneth, A., Bakker, D. C. E., Barbero, L., Bopp, L., Chang, J., Chevallier, F., Chini, L. P., Ciais, P., Fader, M., Feely, R. A., Gkritzalis, T., Harris, I., Hauck, J., Ilyina, T., Jain, A. K., Kato, E., Kitidis, V., Klein Goldewijk, K., Koven, C., Landschützer, P., Lauvset, S. K., Lefèvre, N., Lenton, A., Lima, I. D., Metzl, N., Millero, F., Munro, D. R., Murata, A., Nabel, J. E. M. S., Nakaoka, S., Nojiri, Y., O'Brien, K., Olsen, A., Ono, T., Pérez, F. F., Pfeil, B., Pierrot, D., Poulter, B., Rehder, G., Rödenbeck, C., Saito, S., Schuster, U., Schwinger, J., Séférian, R., Steinhoff, T., Stocker, B. D., Sutton, A. J., Takahashi, T., Tilbrook, B., van der Laan-Luijkx, I. T., van der Werf, G. R., van Heuven, S., Vandemark, D., Viovy, N., Wiltshire, A., Zaehle, S., and Zeng, N.: Global Carbon Budget 2015, Earth Syst. Sci. Data, 7, 349-396, https://doi.org/10.5194/essd-7-349-2015, 2015.

Le Quéré, C., Andrew, R. M., Friedlingstein, P., Sitch, S., Pongratz, J., Manning, A. C., Korsbakken, J. I., Peters, G. P., Canadell, J. G., Jackson, R. B., Boden, T. A., Tans, P. P., Andrews, O. D., Arora, V. K., Bakker, D. C. E., Barbero, L., Becker, M., Betts, R. A., Bopp, L., Chevallier, F., Chini, L. P., Ciais, P., 
Cosca, C. E., Cross, J., Currie, K., Gasser, T., Harris, I., Hauck, J., Haverd, V., Houghton, R. A., Hunt, C. W., Hurtt, G., Ilyina, T., Jain, A. K., Kato, E., Kautz, M., Keeling, R. F., Klein Goldewijk, K., Körtzinger, A., Landschützer, P., Lefèvre, N., Lenton, A., Lienert, S., Lima, I., Lombardozzi, D., Metzl, N., Millero, F., Monteiro, P. M. S., Munro, D. R., Nabel, J. E. M. S., Nakaoka, S.-I., Nojiri, Y., Padin, X. A., Peregon, A., Pfeil, B., Pierrot, D., Poulter, B., Rehder, G., Reimer, J., Rödenbeck, C., Schwinger, J., Séférian, R., Skjelvan, I., Stocker, B. D., Tian, H., Tilbrook, B., Tubiello, F. N., van der Laan-Luijkx, I. T., van der Werf, G. R., van Heuven, S., Viovy, N., Vuichard, N., Walker, A. P., Watson, A. J., Wiltshire, A. J., Zaehle, S., and Zhu, D.: Global Carbon Budget 2017, Earth Syst. Sci. Data, 10, 405-448, https://doi.org/10.5194/essd-10-405-2018, 2018.

Lee, T. N., Yoder, J. A., and Atkinson, L. P.: Gulf Stream frontal eddy influence on productivity of the southeast US continental shelf, J. Geophys. Res.-Ocean., 96, 22191-22205, 1991.

Liu, K.-K., Atkinson, L., Quiñones, R., and Talaue-McManus, L.: Carbon and nutrient fluxes in continental margins: A global synthesis, Springer Science \& Business Media, 2010.

Loder, J. W.: The coastal ocean off northeastern North America: A large-scale view, in: The Sea, edited by: Robinson, A. R. and Brink, K. H., vol. 11, chap. 15, Wiley, 105-138, 1998.

Lohrenz, S. and Verity, P.: Regional oceanography: Southeastern United States and Gulf of Mexico, in: Interdisciplinary Regional Studies and Syntheses, edited by: Robinson, A. R. and Brink, K. H., vol. 14, New York, Wiley \& Sons, 169-224, 2004.

Lohrenz, S. E., Cai, W.-J., Chakraborty, S., Huang, W.-J., Guo, X., He, R., Xue, Z., Fennel, K., Howden, S., and Tian, H.: Satellite estimation of coastal $p \mathrm{CO}_{2}$ and air-sea flux of carbon dioxide in the northern Gulf of Mexico, Remote Sens. Environ., 207, 71-83, 2018.

Mannino, A., Signorini, S. R., Novak, M. G., Wilkin, J., Friedrichs, M. A., and Najjar, R. G.: Dissolved organic carbon fluxes in the Middle Atlantic Bight: An integrated approach based on satellite data and ocean model products, J. Geophys. Res.-Biogeo., 121, 312-336, 2016.

Mathis, J., Sutton, A., Sabine, C., Musielewicz, S., and Maenner, S.: High-resolution Ocean and Atmosphere $p \mathrm{CO}_{2}$ Time-series Measurements from Mooring WA_125W_47N, https://doi.org/10.3334/CDIAC/OTG.TSM_WA_125W_47N, http://cdiac.esd.ornl.gov/ftp/oceans/Moorings/WA_125W_47N/ (last access: 1 May 2018), 2013.

Mathis, J. T., Cross, J. N., Evans, W., and Doney, S. C.: Ocean acidification in the surface waters of the Pacific-Arctic boundary regions, Oceanography, 28, 122-135, 2015.

McGuire, A. D., Anderson, L. G., Christensen, T. R., Dallimore, S., Guo, L., Hayes, D. J., Heimann, M., Lorenson, T. D., Macdonald, R. W., and Roulet, N.: Sensitivity of the carbon cycle in the Arctic to climate change, Ecol. Monogr., 79, 523-555, 2009.

McNeil, B. I. and Matear, R. J.: The non-steady state oceanic $\mathrm{CO}_{2}$ signal: its importance, magnitude and a novel way to detect it, Biogeosciences, 10, 2219-2228, https://doi.org/10.5194/bg-102219-2013, 2013.

Miller, L. A., Macdonald, R. W., McLaughlin, F., Mucci, A., Yamamoto-Kawai, M., Giesbrecht, K. E., and Williams, W. J.: Changes in the marine carbonate system of the western Arctic: Patterns in a rescued data set, Pol. Res., 33, https://doi.org/10.3402/polar.v33.20577, 2014.
Moore, S. E. and Stabeno, P. J.: Synthesis of Arctic Research (SOAR) in marine ecosystems of the Pacific Arctic, Prog. Oceanogr., 136, 1-11, 2015.

Moreau, S., Vancoppenolle, M., Delille, B., Tison, J.-L., Zhou, J., Kotovitch, M., Thomas, D. N., Geilfus, N.-X., and Goosse, H.: Drivers of inorganic carbon dynamics in first-year sea ice: A model study, J. Geophys. Res.-Ocean., 120, 471-495, 2015.

Moreau, S., Vancoppenolle, M., Bopp, L., Aumont, O., Madec, G., Delille, B., Tison, J.-L., Barriat, P.-Y., and Goosse, H.: Assessment of the sea-ice carbon pump: Insights from a threedimensional ocean-sea-ice biogeochemical model (NEMO-LIMPISCES), Elementa: Science of the anthropocene, 4, 000122, https://doi.org/10.12952/journal.elementa.000122, 2016.

Mucci, A., Lansard, B., Miller, L. A., and Papakyriakou, T. N.: $\mathrm{CO}_{2}$ fluxes across the air-sea interface in the southeastern Beaufort Sea: Ice-free period, J. Geophys. Res.-Ocean., 115, C04003, https://doi.org/10.1029/2009jc005330, 2010.

Muller-Karger, F. E., Varela, R., Thunell, R., Luerssen, R., Hu, C., and Walsh, J. J.: The importance of continental margins in the global carbon cycle, Geophys. Res. Lett., 32, L01602, https://doi.org/10.1029/2004g1021346, 2005.

Muller-Karger, F. E., Smith, J. P., Werner, S., Chen, R., Roffer, M., Liu, Y., Muhling, B., Lindo-Atichati, D., Lamkin, J., CerdeiraEstrada, S., and Enfield, D. B.: Natural variability of surface oceanographic conditions in the offshore Gulf of Mexico, Prog. Oceanogr., 134, 54-76, 2015.

Najjar, R., Friedrichs, M., and Cai, W.: Report of The US East Coast carbon cycle synthesis workshop, 19-20 January 2012, 2012.

Najjar, R. G., Herrmann, M., Alexander, R., Boyer, E. W., Burdige, D. J., Butman, D., Cai, W.-J., Canuel, E. A., Chen, R. F., Friedrichs, M. A. M., Feagin, R. A., Griffith, P. C., Hinson, L. A., Holmquist, J. R., Hu, X., Kemp, W. M., Kroeger, K. D., Mannino, A., McCallister, S. L., McGillis, W. R., Mulholland, M. R., Pilskaln, C. H., Salisbury, J., Signorini, S. R., St-Laurent, P., Tian, H., Tzortziou, M., Vlahos, P., Wang, Z. A., and Zimmerman, R. C.: Carbon budget of tidal wetlands, estuaries, and shelf waters of Eastern North America, Global Biogeochem. Cy., 32, 389-416, https://doi.org/10.1002/2017GB005790, 2018.

Orr, J. C., Fabry, V. J., Aumont, O., Bopp, L., Doney, S. C., Feely, R. A., Gnanadesikan, A., Gruber, N., Ishida, A., Joos, F., Key, R. M., Lindsay, K., Maier-Reimer, E., Matear, R., Monfray, P., Mouchet, A., Najjar, R. G., Planer, G. K., Rodgers, K. B., Sabine, C. L., Sarmiento, J. L., Schlitzer, R., Slater, R. D., Toerdell, I. J., Weirig, M. F., Yamanaka, Y., and Yool, A.: Anthropogenic ocean acidification over the twenty-first century and its impact on calcifying organisms, Nature, 437, 681-686, 2005.

Parmentier, F.-J. W., Christensen, T. R., Sørensen, L. L., Rysgaard, S., McGuire, A. D., Miller, P. A., and Walker, D. A.: The impact of lower sea-ice extent on Arctic greenhouse-gas exchange, Nat. Clim. Change, 3, 195-202, 2013.

Pennington, J. T., Friedrich, G. E., Castro, C. G., Collins, C. A., Evans, W. W., , and Chavez, F. P.: The northern and central California upwelling coastal upwelling system, in: Carbon and Nutrient Fluxes in Continental Margins: A Global Synthesis, edited by: Liu, K.-K., Atkinson, L., Quiñones, R. A., and TalaueMcManus, L., Springer, 29-43, 2010.

Peterson, J. O., Morgan, C. A., Peterson, W. T., and Di Lorenzo, E.: Seasonal and interannual variation in the extent of hypoxia 
in the northern California Current from 1998-2012, Limnol. Oceanogr., 58, 2279-2292, 2013.

Phrampus, B. J. and Hornbach, M. J.: Recent changes to the Gulf Stream causing widespread gas hydrate destabilization, Nature, 490, 527-530, 2012.

Previdi, M., Fennel, K., Wilkin, J., and Haidvogel, D.: Interannual variability in atmospheric $\mathrm{CO}_{2}$ uptake on the northeast US continental shelf, J. Geophys. Res.-Biogeo., 114, GB04003, https://doi.org/10.1029/2008jg000881, 2009.

Regnier, P., Friedlingstein, P., Ciais, P., Mackenzie, F. T., Gruber, N., Janssens, I. A., Laruelle, G. G., Lauerwald, R., Luyssaert, S., Andersson, A. J., Arndt, S., Arnosti, C., Borges, A. V., Dale, A. W., Gallego-Sala, A., Goddéris, Y., Goossens, N., Hartmann, J., Heinze, C., Ilyina, T., Joos, F. D., LaRowe, E., Leifeld, J., Meysman, F. J. R., Munhoven, G., Raymond, P. A., Spahni, R., Suntharalingam, P., and Thullner, M.: Anthropogenic perturbation of the carbon fluxes from land to ocean, Nat. Geosci., 6, 597-607, 2013.

Reimer, J. J., Cai, W.-J., Xue, L., Vargas, R., Noakes, S., Hu, X., Signorini, S. R., Mathis, J. T., Feely, R. A., Sutton, A. J., Sabine, C., Musielewicz, S., Chen, B., and Wanninkhof, R.: Time series $p \mathrm{CO}_{2}$ at a coastal mooring: Internal consistency, seasonal cycles, and interannual variability, Cont. Shelf Res., 145, 95-108, 2017.

Rivas, D., Badan, A., and Ochoa, J.: The ventilation of the deep Gulf of Mexico, J. Phys. Oceanogr., 35, 1763-1781, 2005.

Robbins, L., Daly, K., Barbero, L., Wanninkhof, R., He, R., Zong, H., Lisle, J., Cai, W.-J., and Smith, C.: Spatial and temporal variability of $p \mathrm{CO}_{2}$, carbon fluxes and saturation state on the West Florida Shelf, J. Geophys. Res.-Ocean., 123, 6174-6188, https://doi.org/10.1029/2018jc014195, 2018.

Robbins, L. L., Wanninkhof, R., Barbero, L., Hu, X., Mitra, S., Yvon-Lewis, S., Cai, W.-J., Huang, W.-J., and Ryerson, T.: Airsea exchange, in: Report of the U.S. Gulf of Mexico Carbon Cycle Synthesis Workshop, March 27-28, 2013, edited by: Benway, H. M. and Coble, P. G., Ocean Carbon and Biogeochemistry Program and North American Carbon Program, 17-23, 2014.

Rutherford, K. and Fennel, K.: Diagnosing transit times on the northwestern North Atlantic continental shelf, Ocean Sci., 14, 1207-1221, https://doi.org/10.5194/os-14-1207-2018, 2018.

Rykaczewski, R. R. and Checkley, D. M.: Influence of ocean winds on the pelagic ecosystem in upwelling regions, P. Natl. Acad. Sci. USA, 105, 1965-1970, 2008.

Rykaczewski, R. R., Dunne, J. P., Sydeman, W. J., García-Reyes, M., Black, B. A., and Bograd, S. J.: Poleward displacement of coastal upwelling-favorable winds in the ocean's eastern boundary currents through the 21st century, Geophys. Res. Lett., 42, 6424-6431, 2015.

Rysgaard, S., Glud, R. N., Sejr, M., Bendtsen, J., and Christensen, P.: Inorganic carbon transport during sea ice growth and decay: A carbon pump in polar seas, J. Geophys. Res.-Ocean., 112, C03016, https://doi.org/10.1029/2006jc003572, 2007.

Rysgaard, S., Bendtsen, J., Pedersen, L. T., Ramløv, H., and Glud, R. N.: Increased $\mathrm{CO}_{2}$ uptake due to sea ice growth and decay in the Nordic Seas, J. Geophys. Res.-Ocean., 114, C09011, https://doi.org/10.1029/2008jc005088, 2009.

Rysgaard, S., Søgaard, D. H., Cooper, M., Pucko, M., Lennert, K., Papakyriakou, T. N., Wang, F., Geilfus, N. X., Glud, R. N., Ehn, J., McGinnis, D. F., Attard, K., Sievers, J., Deming, J. W., and Barber, D.: Ikaite crystal distribution in winter sea ice and impli- cations for $\mathrm{CO}_{2}$ system dynamics, The Cryosphere, 7, 707-718, https://doi.org/10.5194/tc-7-707-2013, 2013.

Sabine, C. L. and Tanhua, T.: Estimation of anthropogenic $\mathrm{CO}_{2}$ inventories in the ocean, Ann. Rev. Mar. Sci., 2, 175-198, 2010.

Salisbury, J., Vandemark, D., Hunt, C., Campbell, J., Jonsson, B., Mahadevan, A., McGillis, W., and Xue, H.: Episodic riverine influence on surface DIC in the coastal Gulf of Maine, Estuar. Coast. Shelf Sci., 82, 108-118, 2009.

Salisbury, J. E., Vandemark, D., Hunt, C. W., Campbell, J. W., McGillis, W. R., and McDowell, W. H.: Seasonal observations of surface waters in two Gulf of Maine estuary-plume systems: Relationships between watershed attributes, optical measurements and surface $p \mathrm{CO}_{2}$, Estuar. Coast. Shelf Sci., 77, 245-252, 2008.

Shadwick, E. H., Thomas, H., Comeau, A., Craig, S. E., Hunt, C. W., and Salisbury, J. E.: Air-Sea $\mathrm{CO}_{2}$ fluxes on the Scotian Shelf: seasonal to multi-annual variability, Biogeosciences, 7, 38513867, https://doi.org/10.5194/bg-7-3851-2010, 2010.

Shadwick, E. H., Thomas, H., Chierici, M., Else, B., Fransson, A., Michel, C., Miller, L., Mucci, A., Niemi, A., Papakyriakou, T., and Tremblay, J. É.: Seasonal variability of the inorganic carbon system in the Amundsen Gulf region of the southeastern Beaufort Sea, Limnol. Oceanogr., 56, 303-322, 2011.

Shakhova, N., Semiletov, I., Sergienko, V., Lobkovsky, L., Yusupov, V., Salyuk, A., Salomatin, A., Chernykh, D., Kosmach, D., Panteleev, G., Nicolsky, D., Samarkin, V., Joye, S., Charkin, A., Dudarev, O., Meluzov, A., and Gustafsson, O.: The East Siberian Arctic Shelf: Towards further assessment of permafrost-related methane fluxes and role of sea ice, Philos. T. Roy. Soc. A, 373, 20140451, https://doi.org/10.1098/rsta.2014.0451, 2015.

Signorini, S. R., Mannino, A., Najjar, R. G., Friedrichs, M. A., Cai, W.-J., Salisbury, J., Wang, Z. A., Thomas, H., and Shadwick, E.: Surface ocean $p \mathrm{CO}_{2}$ seasonality and sea-air $\mathrm{CO}_{2}$ flux estimates for the North American east coast, J. Geophys. Res.-Ocean., 118, 5439-5460, 2013.

Skarke, A., Ruppel, C., Kodis, M., Brothers, D., and Lobecker, E.: Widespread methane leakage from the sea floor on the northern US Atlantic margin, Nat. Geosci., 7, 657-661, 2014.

Solomon, E. A., Kastner, M., MacDonald, I. R., and Leifer, I.: Considerable methane fluxes to the atmosphere from hydrocarbon seeps in the Gulf of Mexico, Nat. Geosci., 2, 561-565, 2009.

Somero, G. N., Beers, J. M., Chan, F., Hill, T. M., Klinger, T., and Litvin, S. Y.: What changes in the carbonate system, oxygen, and temperature portend for the northeastern Pacific Ocean: A physiological perspective, BioScience, 66, 14-26, 2015.

Steinacher, M., Joos, F., Frölicher, T. L., Plattner, G.-K., and Doney, S. C.: Imminent ocean acidification in the Arctic projected with the NCAR global coupled carbon cycle-climate model, Biogeosciences, 6, 515-533, https://doi.org/10.5194/bg-6-5152009, 2009.

Steiner, N., Lee, W., and Christian, J.: Enhanced gas fluxes in small sea ice leads and cracks: effects on $\mathrm{CO}_{2}$ exchange and ocean acidification, J. Geophys. Res.-Ocean., 118, 1195-1205, 2013.

Steiner, N., Christian, J., Six, K. D., Yamamoto, A., and YamamotoKawai, M.: Future ocean acidification in the Canada Basin and surrounding Arctic Ocean from CMIP5 earth system models, J. Geophys. Res.-Ocean., 119, 332-347, 2014.

Stroeve, J. C., Serreze, M. C., Holland, M. M., Kay, J. E., Malanik, J., and Barrett, A. P.: The Arctic's rapidly shrinking sea ice cover: A research synthesis, Climatic Change, 110, 1005-1027, 2012. 
Sutton, A., Sabine, C., Cai, W.-J., Noakes, S., Musielewicz, S., Maenner, S., Dietrich, C., Bott, R., and Osborne, J.: High-resolution Ocean and Atmosphere $p \mathrm{CO}_{2}$ Timeseries Measurements from Mooring GraysRf_81W_31N, https://doi.org/10.3334/CDIAC/OTG.TSM_GRAYSRF_81W_31N, 2011.

Sutton, A., Sabine, C., Send, U., Ohman, M., Musielewicz, S., Maenner, S., Bott, R., and Osborne, J.: High-resolution Ocean and Atmosphere $p \mathrm{CO}_{2}$ Time-series Measurements from Mooring CCE2_121W_34N (NODC Accession 0084099), Version 4.4, https://doi.org/10.3334/CDIAC/OTG.TSM_CCE2_121W_34N, 2012

Sutton, A., Sabine, C., Salisbury, J., Vandemark, D., Musielewicz, S., Maenner, S., Bott, R., and Osborne, J.: High-resolution Ocean and Atmosphere $p \mathrm{CO}_{2}$ Timeseries Measurements from Mooring NH_70W_43N, https://doi.org/10.3334/CDIAC/OTG.TSM_NH_70W_43N, 2013.

Sutton, A. J., Sabine, C. L., Feely, R. A., Cai, W.-J., Cronin, M. F., McPhaden, M. J., Morell, J. M., Newton, J. A., Noh, J.-H., ÓlafsdÓttir, S. R., Salisbury, J. E., Send, U., Vandemark, D. C., and Weller, R. A.: Using present-day observations to detect when anthropogenic change forces surface ocean carbonate chemistry outside preindustrial bounds, Biogeosciences, 13, 5065-5083, https://doi.org/10.5194/bg-13-5065-2016, 2016.

Sydeman, W., García-Reyes, M., Schoeman, D., Rykaczewski, R., Thompson, S., Black, B., and Bograd, S.: Climate change and wind intensification in coastal upwelling ecosystems, Science, 345, 77-80, 2014.

Takahashi, T., Sutherland, S. C., Wanninkhof, R., Sweeney, C., Feely, R. A., Chipman, D. W., Hales, B., Friederich, G., Chavez, F., Sabine, C., Watson, A., Bakker, D. C. E., Schuster, U., Metzl, N., Yoshikawa-Inoue, H., Ishii, M., Midorikawa, T., Nojiri, Y., Körtzinger, A., Steinho, T., Hoppema, M., Olafsson, J., Arnarson, T. S., Tilbrook, B., Johannessen, T., Olsen, A., Bellerby, R., Wong, C. S., Delille, B., Bates, N. R., and de Baar, H. J. W.: Climatological mean and decadal change in surface ocean $p \mathrm{CO}_{2}$, and net sea-air $\mathrm{CO}_{2}$ flux over the global oceans, Deep-Sea Res. Pt. II, 56, 554-577, 2009.

Tsunogai, S., Watanabe, S., and Sato, T.: Is there a "continental shelf pump" for the absorption of atmospheric $\mathrm{CO}_{2}$ ?, Tellus $\mathrm{B}, 51$, 701-712, 1999.

Turi, G., Lachkar, Z., and Gruber, N.: Spatiotemporal variability and drivers of $p \mathrm{CO}_{2}$ and air-sea $\mathrm{CO}_{2}$ fluxes in the California Current System: an eddy-resolving modeling study, Biogeosciences, 11, 671-690, https://doi.org/10.5194/bg-11-671-2014, 2014.

Turi, G., Lachkar, Z., Gruber, N., and Münnich, M.: Climatic modulation of recent trends in ocean acidification in the California Current System, Environ. Res. Lett., 11, 014007, https://doi.org/10.1088/1748-9326/11/1/014007, 2016.

Turk, D., Bedard, J., Burt, W., Vagle, S., Thomas, H., Azetsu-Scott, K., McGillis, W., Iverson, S., and Wallace, D.: Inorganic carbon in a high latitude estuary-fjord system in Canada's eastern Arctic, Estuar. Coast. Shelf Sci., 178, 137-147, 2016.

van der Loeff, M. M. R., Cassar, N., Nicolaus, M., Rabe, B., and Stimac, I.: The influence of sea ice cover on air-sea gas exchange estimated with radon-222 profiles, J. Geophys. Res.-Ocean., 119, 2735-2751, 2014.
Vandemark, D., Salisbury, J., Hunt, C., Shellito, S., Irish, J., McGillis, W., Sabine, C., and Maenner, S.: Temporal and spatial dynamics of $\mathrm{CO}_{2}$ air-sea flux in the Gulf of Maine, J. Geophys. Res.-Ocean., 116, C01012, https://doi.org/10.1029/2010jc006408, 2011.

Vlahos, P., Chen, R. F., and Repeta, D. J.: Dissolved organic carbon in the Mid-Atlantic Bight, Deep-Sea Res. Pt. II, 49, 4369-4385, 2002.

Waldbusser, G. G., Hales, B., Langdon, C. J., Haley, B. A., Schrader, P., Brunner, E. L., Gray, M. W., Miller, C. A., and Gimenez, I.: Saturation-state sensitivity of marine bivalve larvae to ocean acidification, Nat. Clim. Change, 5, 273-280, 2015.

Walker Brown, C., Boutin, J., and Merlivat, L.: New insights into $f \mathrm{CO}_{2}$ variability in the tropical eastern Pacific Ocean using SMOS SSS, Biogeosciences, 12, 7315-7329, https://doi.org/10.5194/bg-12-7315-2015, 2015.

Wang, Z. A. and Cai, W.-J.: Carbon dioxide degassing and inorganic carbon export from a marsh-dominated estuary (the Duplin River): A marsh $\mathrm{CO}_{2}$ pump, Limnol. Oceanogr., 49, 341-354, 2004.

Wang, Z. A., Cai, W.-J., Wang, Y., and Ji, H.: The southeastern continental shelf of the United States as an atmospheric $\mathrm{CO}_{2}$ source and an exporter of inorganic carbon to the ocean, Cont. Shelf Res., 25, 1917-1941, 2005.

Wang, Z. A., Wanninkhof, R., Cai, W.-J., Byrne, R. H., Hu, X., Peng, T.-H., and Huang, W.-J.: The marine inorganic carbon system along the Gulf of Mexico and Atlantic coasts of the United States: Insights from a transregional coastal carbon study, Limnol. Oceanogr., 58, 325-342, 2013.

Wang, Z. A., Lawson, G. L., Pilskaln, C. H., and Maas, A. E.: Seasonal controls of aragonite saturation states in the Gulf of Maine, J. Geophys. Res.-Ocean., 122, 372-389, 2017.

Wanninkhof, R. and Trinanes, J.: The impact of changing wind speeds on gas transfer and its effect on global air-sea $\mathrm{CO}_{2}$ fluxes, Global Biogeochem. Cy., 31, 961-974, 2017.

Wanninkhof, R., Barbero, L., Byrne, R., Cai, W.-J., Huang, W.-J., Zhang, J.-Z., Baringer, M., and Langdon, C.: Ocean acidification along the Gulf Coast and East Coast of the USA, Cont. Shelf Res., 98, 54-71, 2015.

Weber, T. C., Mayer, L., Jerram, K., Beaudoin, J., Rzhanov, Y., and Lovalvo, D.: Acoustic estimates of methane gas flux from the seabed in a $6000 \mathrm{~km}^{2}$ region in the Northern Gulf of Mexico, Geochem. Geophy. Geosy., 15, 1911-1925, 2014.

Windham-Myers, L., Cai, W.-J., Alin, S., Andersson, A., Crosswell, J., Dunton, K. H., Hernandez-Ayon, J. M., Herrmann, M., Hinson, A. L., Hopkinson, C. S., Howard, J., Hu, X., Knox, S. H., Kroeger, K., Lagomasino, D., Megonigal, P., Najjar, R. G., Paulsen, M.-L., Peteet, D., Pidgeon, E., Schäfer, K. V. R., Tzortziou, M., Wang, Z. A., and Watson, E. B.: Chapter 15: Tidal wetlands and estuaries, in: Second State of the Carbon Cycle Report (SOCCR2): A Sustained Assessment Report, edited by: Cavallaro, N., Shrestha, G., Birdsey, R., Mayes, M. A., Najjar, R. G., Reed, S. C., Romero-Lankao, P., and Zhu, Z., US Global Change Research Program, Washington, DC, USA, 596648, 2018.

Xue, L., Cai, W.-J., Hu, X., Sabine, C., Jones, S., Sutton, A. J., Jiang, L.-Q., and Reimer, J. J.: Sea surface carbon dioxide at the Georgia time series site (2006-2007): Air-sea flux and controlling processes, Prog. Oceanogr., 140, 14-26, 2016. 
Xue, Z., He, R., Fennel, K., Cai, W.-J., Lohrenz, S., and Hopkinson, C.: Modeling ocean circulation and biogeochemical variability in the Gulf of Mexico, Biogeosciences, 10, 7219-7234, https://doi.org/10.5194/bg-10-7219-2013, 2013.

Xue, Z., He, R., Fennel, K., Cai, W.-J., Lohrenz, S., Huang, W.J., Tian, H., Ren, W., and Zang, Z.: Modeling $p \mathrm{CO}_{2}$ variability in the Gulf of Mexico, Biogeosciences, 13, 4359-4377, https://doi.org/10.5194/bg-13-4359-2016, 2016.

Yamamoto-Kawai, M., McLaughlin, F., and Carmack, E.: Ocean acidification in the three oceans surrounding northern North America, J. Geophys. Res.-Ocean., 118, 6274-6284, 2013.
Yasunaka, S., Murata, A., Watanabe, E., Chierici, M., Fransson, A., van Heuven, S., Hoppema, M., Ishii, M., Johannessen, T., Kosugi, N., Lauvset, S. K., Mathis, J. T., Nishino, S., Omar, A. M., Olsen, A.,, Sasano, Takahashi, T., and Wanninkhof, R.: Mapping of the air-sea $\mathrm{CO}_{2}$ flux in the Arctic Ocean and its adjacent seas: Basin-wide distribution and seasonal to interannual variability, Polar Sci., 10, 323-334, 2016. 